\title{
THE TREMATODE PARASITES OF MARINE MAMMALS
}

\author{
By Емmett W. Price \\ Parasitologist, Zoological Division, Bureau of Animal Industry \\ United States Department of Agriculture
}

The internal parasites of marine mammals have not been extensively studied, although a fairly large number of species have been described. In attempting to identify the trematodes from mammals of the orders Cetacea, Pinnipedia, and Sirenia, as represented by specimens in the United States National Museum helminthological collection, it was necessary to review the greater part of the literature dealing with this group of parasitic worms. In view of the fact that there is not in existence a single comprehensive paper on the trematodes of these mammals, and that many of the descriptions of species have appeared in publications having more or less limited circulation, the writer has undertaken to assemble descriptions of all trematodes reported from these hosts, with the hope that such a paper may serve a useful purpose in aiding other workers in determining specimens at their disposal.

In addition to compiling the deseriptions of species not available to the writer, two new species, one of which represents a new genus, have been described. Specimens representing 10 of the previously described species have been studied and emendations or additions have been made to the existing descriptions; in a few instances the species have been completely redescribed.

Three species, Distomum pallassii Poirier, D. validum von Linstow, and $D$. ampullaceum Buttel-Reepen, have been omitted from this paper despite the fact that they have been reported from cetaceans. These species belong in the family Hemiuridae, and since all species of this family are parasites of fishes, the writer feels that their reported occurrence in mammals may be regarded as either errors of some sort or cases of accidental parasitism in which fishes have been eaten by mammals and the fish parasites found in the mammal post-mortem. Buttel-Reepen (1902) has pointed out, in connection with the reported occurrence of $D$. ampullaceum in a cetacean, that sailors commonly designate species of mackerel as "Delphin " or "Dolphyn (holländisch)." It appears likely, there- 
fore, that in this case these terms for fishes have been interpreted to mean a dolphin and that these fish parasites have been erroneously listed as parasites of cetaceans.

In the compiled descriptions all measurements when less than $1 \mathrm{~mm}$ have been given in microns, when more than $0.5 \mu$ the fraction has been counted as $1 \mu$, and if less the fraction has been discarded.

The trematodes of marine mammals which may be considered valid or recognizable forms comprise 30 species belonging to nine families: Fasciolidae Railliet, Echinostomatidae Looss, Troglotrematidae Odhner, Opisthorchiidae Braun, Heterophyidae Odhner, Paramphistomatidae Fischoeder, Notocotylidae Lühe, Opisthotrematidae Poche, and Rhabdiopoeidae Poche. These families may be differentiated by the following key:

KEY TO FAMILIES OF TREMATODE PARASITES OF MARINE MAMMALS

1. Body provided with two suckers; eggs without polar filaments 2.

Body provided with only one sucker; eggs with polar filaments 7.

2. Acetabulum or ventral sucker situated at posterior end of body.

Paramphistomatidae (p. 41).

Acetabulum situated in anterior half of body 3.

3. Anterior end of body provided with a kidney-shaped collar armed with one to two rows of large spines Echinostomatidae (p. 21).

Anterior end of body without collar as above

4. Usually large flukes, either flat and leaflike, slightly flattened, or cylindrical; cirrus pouch and cirrus present; seminal receptacle very small or absent Fasciolidae (p. 3).

Medium-sized to very small flukes, usually oval and flattened; cirrus pouch and cirrus absent; seminal receptacle large and conspicuous

5. Body spindle shaped; occurring in cysts, usually in pairs.

Troglotrematidae (p. 23).

Body flat, not occurring in cysts

6. Body covered with small, scalelike spines; acetabulum inclosed in the genital sinus; parasites of the intestinal tract.

Heterophyidae (p. 33).

Body usually without spines; acetabulum not inclosed in the genital sinus; parasites of the gall bladder or bile ducts.

7. Genital pore situated at extreme posterior end of body.

Opisthorchiidae (p. 25).

Opisthotrematidae (p. 48).

Genital pore near anterior end of body 8.

S. Ventral surface of body usually provided with longitudinal rows of glands, or rugae; vitellaria pretesticular; without proboscid complex in posterior part of body.

Notocotylidae (p. 44).

Ventral surface of body without rows of glands, or rugae; vitellaria posttesticular; proboscid complex in posterior part of body

Rhabdiopoeidae (p. 47). 
Family FASCIOLIDAE Railliet, 1895

Synonyms.-Fasciolopsidae Odhner, 1926, p. 4; Campulidae Odhner, 1926, p. 5 ; Brachycladiidae Faust, 1929, p. 88.

Family diagnosis.-Large flat forms; suckers relatively close together; cuticle with or without spines. Intestinal ceca simple or with lateral dendritic branches. Excretory bladder simple and tubelike, or profusely branched. Genital pore preacetabular; cirrus pouch present; cirrus armed or unarmed. Testes usually profusely branched, but may be without branches or lobes. Ovary branched or entire; seminal receptacle reduced or absent; Laurer's canal present. Vitellaria profusely developed, consisting of numerous follicles situated along the sides of the body and becoming confluent posteriorly. Uterus with relatively few coils; eggs large, either circular or triangular in cross section.

Type genus.-Fasciola Linnaeus, 1758.

KEY TO SUBFAMILIES OF FASCIOLIDAE CONTAINING SPECIES PARASitic IN MARINE MAMMALS

1. Body flat, leaflike; testes and ovary profusely branched; eggs without thickening at posterior pole, circular in cross section.

Fasciolinae (p. 3).

Body elongated and slightly flattened, but not leaflike; testes and ovary usually unbranched; eggs with thickening at posterior pole, usually triangular in cross section__._- Campulinae (p. 5).

\section{Subfamily Fasciolinae Stiles and Hassall, 1898}

Subfamily diagnosis.-Fasciolidae: Body flat and leaflike. Intestinal ceca profusely branched, the branches being dendritic and mainly lateral. Excretory vesicle with lateral branches. Testes profusely branched; cirrus pouch not extending beyond posterior margin of acetabulum; cirrus unarmed. Ovary branched. Eggs without thickening at posterior pole, circular in cross section. Parasites of herbivorous or omnivorous mammals.

Type genus.-Fasciola Linnaeus, 1758.

\section{Genus FASCIOLA Linnaeus, 1758}

Generio diagnosis.-Fasciolinae: Body large, broad, flat, and leaflike; anterior end conical, forming a cephalic cone, which is set off from the wider, flattened, leaflike portion. Cuticle armed with scalelike spines. Oral sucker subterminal; acetabulum at base of cephalic cone. Prepharynx short; pharynx well developed; esophagus short; intestinal ceca long, extending to posterior end of body and provided with numerous, long, dendritic lateral branches, and fewer, shorter, 
median branches. Excretory vesicle long and slender, with numerous lateral branches, which anastomose to form an extensive dorsal and ventral network. Genital pore preacetabular, situated at base of cephalic cone; cirrus pouch not extending caudally beyond posterior margin of acetabulum; testes profusely branched, tandem in position, and situated in the equatorial zone. Ovary branched, pretesticular, situated to one side of median line; seminal receptacle absent; Laurer's canal present. Vitellaria very profusely developed, extending from base of cephalic cone to posterior end of body, completely filling posttesticular area, and extending both dorsal and ventral to intestinal ceca. Uterus coiled in the form of a rosette, situated between acetabulum and ovary. Eggs large, without thickening of posterior pole, circular in cross section. Parasitic in bile ducts of herbivorous and omnivorous mammals.

Type species.-Fasciola hepatica Linnaeus, 1758.

\section{FASCIOLA HEPATICA Linnaeus, 1758}

Plate 1, Figure 1

Synonyms.-Planaria latiuscula Goeze, 1782, p. 169; Distoma hepaticum (Linnaeus, 1758) Abildgaard (?) ; Fasciola humana Gmelin, 1790, p. 3053; Fasciolaria hepatica Encycl. Metropolitana, 1845, p. 141; Distomum caviae Sonsino, 1890, p. 100; Cladocoelium hepaticum (Linnaeus, 1758) Stossich, 1892, p. 7.

Description.-Fasciola: Body flat and leaflike, $13 \mathrm{~mm}$ long by 3.7 $\mathrm{mm}$ wide in region of ovary; cephalic cone $1 \mathrm{~mm}$ long. No cuticular spines were present on the specimen examined by the writer. Oral sucker subterminal, $387 \mu$ long by $542 \mu$ wide; acetabulum transversely oval, $542 \mu$ long by $697 \mu$ wide, situated $1.2 \mathrm{~mm}$ from anterior end of body. Digestive tract as described for $F$. hepatica by other writers. Testes profusely branched, occupying the entire intercecal field from the level of the ovary to about one-fourth of the body length from the posterior end. Cirrus pouch ovoid, not extending caudad beyond center of acetabulum; cirrus strongly muscular, not protruded. Ovary branched, situated to right of median line immediately cephalad of testis; Mehlis's gland globular, $341 \mu$ in diameter, situated in median line. Vitellaria profusely developed, extending to level of acetabulum on the right side, but stopping abruptly about $1 \mathrm{~mm}$ caudad of acetabulum on the left side; caudally the vitelline follicles completely fill the posttesticular area. Uterus closely coiled and occupying the intercecal field between the anterior testis and acetabulum; genital pore $186 \mu$ cephalad of anterior margin of acetabulum. Eggs oval, $120 \mu$ to $127 \mu$ long by $60 \mu$ to $67 \mu$ wide.

Hosts.-Herbivorous mammals and man; marine mammals (Orcinus orca $=$ Orca gladiator; Balaenoptera acutorostrata $=B$. rostrata). 
Location.-Bile ducts for marine mammals, and usually for other animals.

Distribution.-Europe (for B. acutorostrata and Orcinus orca). Remarks.-The description of Fasciola hepatica given here is based upon a carmine-stained toto mount, which Dr. C. W. Stiles kindly loaned the writer for study, it being one of the specimens referred to below. Aside from a few slight differences, such as body size and a slightly smaller egg, this fluke so closely resembles $F$. hepatica from ruminants that it must be regarded as the same species.

There appear to be only two records of Fasciola hepatica from marine mammals. Stiles and Hassall (1894) record this species from Orca gladiator, and later Stiles (1894, p. 302) states: "Leuckart once gave me two specimens of a fluke, which I still have in my possession, labeled 'Leber, Schwert-fisch.' I am unable to distinguish this fluke from Fasciola hepatica. I assume that this ' Schwert fish' is Orca gladiator rather than Xiphias gladius, as all the other hosts of $F$. hepatica are mammals." Odhner (1905) notes that he found a fragment of $F$. hepatica in a vial labeled "Distoma gotiath van Ben.," in the Kopenhagen Museum. Odhner believed that this was a case of mislabeling and regarded it as unthinkable that a whale could have become infested with this fluke.

The two records cited above may have been the result of mislabeling, but if so it is quite remarkable that two such instances should have occurred in which the hosts cited were cetaceans.

\section{Subfamily Campulinae Stunkard and Alvey, 1930}

Synonym.-Brachycladiinae Odhner, 1910c, p. 165.

Subfamily diagnosis.-Fasciolidae: Elongated, medium-sized to very large flukes; body relatively narrow and thick. Cuticle armed with relatively large, pointed spines. Suckers close together in some genera and rather widely separated in others. Digestive system $\mathrm{H}$ shaped, except in Odhneriella; anterior ceca short; posterior ceca long, sinuous and extending to posterior end of body; diverticula, when present, are both median and lateral. Excretory vesicle tubelike, without lateral branches. Genital aperture preacetabular; cirrus pouch frequently extends far caudad of acetabulum; cirrus armed or unarmed. Testes slightly or deeply lobed, or smooth, tandem in position, and situated not far caudad of ovary. Ovary smooth or slightly lobed; seminal receptacle much reduced in size or absent; Laurer's canal present. Vitellaria well developed. Uterus with relatively few loops; vagina with or without spines. Eggs with thickened posterior pole, usually triangular in cross section. Parasites of marine mammals.

Type genus.-Campula Cobbold, 1858. 
KEY TO THE GENERA OF THE SUBFAMILY CAMPULINAE

1. Cirrus unarmed

Cirrus armed

2. Body slender, $60 \mathrm{~mm}$ to $80 \mathrm{~mm}$ long; ovary deeply lobed; vitellaria in more or less rectangular masses of follicles_ Lecithodesmus (p. 11).

Body more robust, less than $20 \mathrm{~mm}$ long; ovary not lobed; vitellaria not as above

3. Oral sucker much larger than acetabulum; eggs circular in cross section

Zalophotrema (p. 13).

Oral sucker and acetabulum about equal in size; eggs triangular in cross section Campula (p. 6).

4. Vagina unarmed; vitelline follicles in distinct masses

Vagina armed; vitelline follicles not in distinct masses

5. Anterior ceca absent; in liver of pinnipeds Odhneriella (p. 20).

Anterior ceca present; in intestine of cetaceans Hadwenius (p. 17).

6. Testes deeply lobed; intestinal ceca with median and lateral diverticula

Synthesium (p. 16).

Testes not deeply lobed; intestinal ceca without median and lateral diverticula

Orthosplanchnus (p. 14).

\section{Genus CAMPULA Cobbold, 1858}

Synonym.-Brachycladium Looss, 1899, p. 558.

Generic diagnosis.-Campulinae: Body elongated and slightly flattened; posterior end usually more pointed than anterior end. Cuticle completely covered with large, pointed spines. Oral sucker slightly smaller than acetabulum. Intestinal ceca with short median and lateral diverticula. Excretory vesicle tubelike, extending anteriorly to ovary. Genital pore immediately cephalad of acetabulum; cirrus pouch short; cirrus unarmed; testes with or without lobes, never dendritic. Ovary entire, pretesticular; seminal receptacle reduced; Laurer's canal present. Vitellaria profusely developed, extending anteriorly to level of pharynx. Uterus with few coils. Eggs triangular in cross section.

Type species.—Campula oblonga Cobbold, 1858.

KEY TO SPECIES OF THE GENUS CAMPULA

1. Testes lobed

2.

Testes not lobed 3.

2. Cirrus pouch not extending caudad of acetabulum; intestinal branches without anal openings palliata (p. 9).

Cirrus pouch extending caudad of acetabulum; intestinal branches with anal openings oblonga (p. 7).

3. Suckers close together; testes preequatorial rochebruni (p. 11).

Suckers widely separated; testes in posterior third of body_ delphini (p. 9). 
Synonyms.-Distomum oblongum (Cobbold, 1858) Braun, 1892, p. 99; Distomum (Brachylaimus) oblongum (Cobbold, 1858) Stossich, 1892, pp. 16-17; Brachycladium oblongum (Cobbold, 1858) Looss, 1902, p. 716; Distomum tenuicolle Rudolphi of Olsson, 1893, p. 9.

Description.-Campula: Body elongate, 4 to $7 \mathrm{~mm}$ long by 1 to $3 \mathrm{~mm}$ wide, anterior end obtuse, posterior end rounded. Cuticle armed with pointed spines, $44 \mu$ long by $14 \mu$ wide, arranged in alternating transverse rows. Oral sucker subterminal, $310 \mu$ to $340 \mu$ in diameter; acetabulum $430 \mu$ to $465 \mu$ in diameter, situated a little less than one-fourth of the body length from the anterior end. Prepharynx very short and wide; pharynx piriform, $310 \mu$ to $360 \mu$ long by $170 \mu$ to $220 \mu$ wide; esophagus about $100 \mu$ long. The short, anteriorly directed, intestinal ceca extend beyond posterior margin of the oral sucker and are not provided with lateral diverticula; the posteriorly directed branches are more or less zigzag and extend to the posterior end of the body, where they open into a depression in common with the excretory vesicle; the posterior branches of the intestine are provided with short median and lateral diverticula. The excretory vesicle is tubelike and extends anteriorly, dorsal to testes, to the level of the posterior margin of the ovary; it is slender at the posterior end, but becomes progressively wider anteriorly. The genital aperture is situated immediately cephalad of the acetabulum; genital sinus small. Cirrus pouch somewhat pestle shaped, slightly curved, and extending caudad to a point about midway between the posterior margin of acetabulum and the anterior margin of ovary. The greater part of the cirrus pouch is filled with a sinuous seminal vesicle. Cirrus unarmed, protrusible. The testes are deeply lobed, tandem in position, and occupy the equatorial third of the body; the anterior testis is $620 \mu$ to $770 \mu$ long by $770 \mu$ to $990 \mu$ wide, and the posterior testis in $620 \mu$ to $1 \mathrm{~mm}$ long by $770 \mu$ to $1.2 \mathrm{~mm}$ wide. Ovary transversely oval, $186 \mu$ to $372 \mu$ long by $310 \mu$ to $527 \mu$ wide, situated immediately cephalad of anterior testis and to the right of the median line. Seminal receptacle greatly reduced in size or (?) absent (Nicoll described a small seminal receptacle, but the writer has been unable to demonstrate this structure in the specimens at his disposal); Laurer's canal present. Vitellaria abundantly developed, the follicles being distributed over the entire dorsal surface from the level of the posterior end of the esophagus to the posterior end of body; ventrally 
the follicles do not extend medially much beyond the inner limits of the intestine in the testicular and pretesticular zones, but completely fill the posttesticular zone. The uterus is relatively short, consisting of a few loops confined to the intercecal field between the ovary and acetabulum; vagina about one-half the length of cirrus pouch, muscular, and without spines. Eggs $90 \mu$ to $97 \mu$ long by $45 \mu$ wide, oval in outline, but more or less triangular in cross section; shell yellow, thickened to form a knoblike projection at posterior pole; opercular pole flat.

Host.-Phocaena phocoena (=Phocaena communis).

Location.-Bile ducts.

Distribution.-Europe; North America (United States).

Remarks.-The above description is based upon specimens (U.S.N.M. Helm. Coll. No. 8415) collected by Dr. G. A. MacCallum, June 27, 1925, from the liver of Phocaena phocoena at Woods Hole, Mass. Two additional lots of specimens have also been examined. The first of these (U.S.N.M. Helm. Coll. No. 3379) was collected by Prof. Max Braun from the liver of Phocaena communis at Warnemünde, and identified as Campula oblonga. The date of collection is not given, but it is probable that this is a part of the material upon which his (1900) description of this species is based. The second lot of specimens (U.S.N.M. Helm. Coll. No. 16682) is labeled "Campula oblonga, liver, Phocaena communis, Millport, August 15, 1908, determined by Wm. Nicoll." In the case of this material, there appears to be no doubt that this represents a part of the specimens described by Nicoll in 1909. The specimens comprising both of these lots agree in all essentials with those from the MacCallum collection.

One of the outstanding characters which distinguish $C$. oblonga from all other species of the genus is the presence of anal openings. These structures are quite distinct and were found to occur in all specimens examined.

Anal openings have been reported as occurring in species belonging to the family Echinostomatidae by Leiper (1908) and by Odhner (1910c) ; in the Steringophoridae by Odhner (1911); in the Accacoeliidae by Looss (1912); in the Azygiidae and Allocreadiidae, and in Schistorchis carneus (syn. Pleorchis oligorchis; family uncertain) by Odhner $(1928)$; in the Opecoelidae by Ozaki $(1925 ; 1928)$; and in the Diploproctodaeidae by LaRue (1926) and by Ozaki (1928). Stunkard (1930) also demonstrated the presence of these openings in Distomum sp. of Linton, 1899, and proposed a new genus and species, Bianium concavum, for this trematode.

The genetic significance of the occurrence of anal openings in these worms is not clear. In two of the families, Opecoelidae and Diploproctodaeidae, these structures are present in all species in- 
cluded in these groups; in other families, however, this does not hold true. So far as the family Fasciolidae is concerned, $C$. oblonga is the only species known to possess these structures; it appears, therefore, that anal openings in some species are characters of specific rather than generic or family significance.

\section{CAMPUla PAlliata (Looss, 1885) Looss, 1901}

\section{Plate 2, Figures 6-7}

Synonyms.-Distomum palliatum Looss, 1885, pp. 390-427; Brachycladium palliatum (Looss, 1885) Looss, 1899, p. 558; Cladocoelium palliatum (Looss, 1885) Stossich, 1892, pp. 10-11.

Description.-Campula: Body elongated, $9 \mathrm{~mm}$ to $10 \mathrm{~mm}$ long by $1.5 \mathrm{~mm}$ to $2 \mathrm{~mm}$ wide and $750 \mu$ to $1 \mathrm{~mm}$ thick; the anterior end is more rounded than the posterior end, and there is a definite constriction of the body in the vicinity of the acetabulum. Cuticle armed with closely set rows of pointed spines, $62 \mu$ to $76 \mu$ long by $5 \mu$ to $8 \mu$ wide, which completely cover the body. Suckers about equal in size and situated $2.5 \mathrm{~mm}$ to $3.5 \mathrm{~mm}$ apart. Pharynx ovoid, $380 \mu$ long by $293 \mu$ wide; esophagus $540 \mu$ wide. The intestinal tract consists of a pair of anteriorly directed ceca, one on each side, which extend to the level of the oral sucker, and a pair of posteriorly directed ceca, which extend to the posterior end of the body, both pairs of ceca being provided with short median and lateral diverticula. Excretory vesicle tubular, extending anteriorly dorsal of testes and dividing into two branches. Genital aperture median and situated a short distance cephalad of acetabulum. Cirrus pouch strongly muscular and situated mostly in front of acetabulum; it contains the seminal vesicle, ejaculatory duct, and cirrus. Testes lobed, tandem in position, situated in posterior part of middle third of body. Ovary irregular in outline, $489 \mu$ in greatest diameter, situated to left of median line and cephalad of anterior testis; seminal receptacle small ; Laurer's canal present. Vitellaria abundantly developed and consisting of grapelike follicles, which extend from region of pharynx to posterior end of intestinal ceca. Uterus consists of numerous coils situated dorsal to acetabulum. Eggs $59 \mu$ long by $43 \mu$ wide, ellipsoidal, the opercular pole blunter than the posterior pole. Host.-Delphinus delphis.

Location.-Liver (bile ducts).

Distribution.-Europe.

CAMPULA DELPHINI (Poirier, 1886) Bittner and Sprehn, 1928

Plate 2, Figures 8-10

Synonyms.-Distomum delphini Poirier, 1886, pp. 34-36; Cladocoelium delphini (Poirier, 1886) Stossich, 1892, p. 10; Brachycladium delphini (Poirier, 1886) Looss, 1899, p. 558. 
Description.-Campula: Body flat, $14 \mathrm{~mm}$ long by $2 \mathrm{~mm}$ wide, slightly attenuated at the extremities. Cuticle covered with small slender spines. Suckers about equal in size; acetabulum $700 \mu$ in diameter, oral sucker slightly smaller; distance between suckers 7 $\mathrm{mm}$. Prepharynx short and wide; pharynx piriform in shape, $700 \mu$ long by $400 \mu$ wide; esophagus very short; intestine with short, anteriorly directed ceca, one on each side, which extend to the level of the oral sucker, and long posterior ceca, which extend to the posterior end of the body. The anterior ceca are provided with three more or less well-developed lateral diverticula, and the posterior ceca are provided with short diverticula throughout their course, especially along their lateral margins. Genital aperture median, situated a short distance cephalad of acetabulum; cirrus pouch short and wide, containing the seminal vesicle, short prostatic canal, and a poorly developed ejaculatory duct, and situated entirely in front of acetabulum. Testes large, ovoid, tandem in position, and situated in anterior part of the posterior third of body. Ovary small, spherical, situated cephalad of anterior testis and to the right of median line; Mehlis's gland well developed, to left of ovary; Laurer's canal present. Vitellaria well developed and occupying almost the entire surface of body, both dorsally and ventrally; they are composed of tubular glands entangled to form a compact network; the vitelline ducts unite cephalad of the genital aperture and caudad of posterior testis, and also between ovary and anterior testis where they form the vitelline reservoir. Uterus sinuous, situated between Mehlis's gland and genital aperture. Eggs elliptical, $60 \mu$ long by $45 \mu$ wide, slightly pointed posteriorly.

Host.-Delphinus delphis.

Location.-Liver (bile ducts).

Distribution.-Europe.

Remarks.-Odhner (1905) was of the opinion that this species was probably identical with Brachycladium palliatum Looss (=Campula palliata), since he stated: "Ich bin nämlich nicht völlig überzeugt, dass Br. delphini nicht mit dem demselben Wirte entstammenden $\mathrm{Br}$. palliatum am Ende zusammenfallen könnte. Die Differenze in der Form der Hoden dürfte für das Auseinanderhalten der beiden Arten kaum genügen." Odhner's point regarding the form of the testes is well taken, but there are other characters which appear definitely to eliminate the likelihood of the two species being identical. In Campula palliata the uterus forms a rosette mass of coils dorsal to the acetabulum, the egg does not show a definite polar prolongation or thickening, and the anterior and posterior vitelline ducts do not anastomose. In $C$. delphini the uterus lies caudad of the acetabulum, the egg shows a marked polar thickening or prolongation, and the vitelline ducts anastomose anterior to the genital 
aperture and posterior to the posterior testis. Despite the fact that Poirier's (1886) description of $C$. delphini is so somewhat incomplete, the writer feels that a restudy of specimens of this species will show it to be specifically distinct from $C$. palliata and perhaps to belong to a difierent genus. Aside from the shape of the ovary and testes, it appears to be more closely related to the genus Lecithodesmus than to the genus Campula, but the writer prefers to leave it in the latter genus until an examination of specimens of these forms is possible.

CAMPULA ROCHEBRUNI (Peirier, 1886) Bittner and Sprehn, 1928

\section{Plate 3, Figures 11-12}

Synonyms.-Distomum rochebruni Poirier, 1886, pp. 36-37; Cladocoetium rochebruni (Poirier, 1886) Stossich, 1892, p. 11; Brachycladium rochebruni (Poirier, 1886) Looss, 1899, p. 558.

Description.-Campula: Body narrow, $10 \mathrm{~mm}$ long by $1 \mathrm{~mm}$ wide; ventral surface flat, dorsal surface slightly convex. Cuticle beset with very slender spines, which are especially abundant and close together on the anterior part of body. Suckers equal in size, $380 \mu$ in diameter (Poirier gives the diameter as $0.038 \mathrm{~mm}$, but this undoubtedly is an error for $0.38 \mathrm{~mm}$ ) and $700 \mu$ apart. Pharynx $490 \mu$ long by $180 \mu$ wide; esophagus very short; intestine as in $C$. delphini. Genital aperture immediately cephalad of acetabulum; cirrus pouch short and wide, preacetabular. Testes large, ovoid, tandem in position, and situated near equator of body. Ovary small, spherical, situated cephalad of anterior testis and to right of median line; Mehlis's gland more elongated and situated to left of ovary. Vitellaria composed of anastomosing tubular glands and extending over the greater part of body; the vitelline ducts do not anastomose in the anterior and posterior parts of body as in $C$. delphini. Uterus with few loops, situated between Mehlis's gland and genital sinus. Eggs oval, $82 \mu$ long by $45 \mu$ wide, strongly pointed posteriorly.

Host.-Delphinus delphis.

Location.-Liver.

Distribution.-Europe.

Genus LECITHODESMUS Braun, 1902

Generic diagnosis.-Campulinae: Body long, slender, and flattened dorsoventrally. Suckers widely separated. Intestinal ceca provided with median and lateral dendritic diverticula. Cirrus pouch extending slightly beyond posterior margin of acetabulum; cirrus unarmed; testes branched. Ovary deeply lobed; vitellaria in quadrangular groups of follicles extending from region of pharynx to posterior end of body. Parasites of cetaceans.

Type species.-Lecithodesmus goliath (van Beneden, 1858) Odhner, 1905 . 
Plate 3, Figures 15-16

Synonym.-Distomum goliath van Beneden, 1858, pp. 95-97.

Description.-Lecithodesmus: Body ribbonlike, 60 to $80 \mathrm{~mm}$ long by $8 \mathrm{~mm}$ wide and 1.6 to $1.8 \mathrm{~mm}$ thick (90 $\mathrm{mm}$ long by $9 \mathrm{~mm}$ wide, according to Lönnberg, 1891), anterior end bluntly rounded and posterior end slightly attenuated. Spines present on anterior part of body. [Odhner (1905) believes that the absence of spines on the posterior part is due to the effects of maceration for several days of habitual delay before specimens can be collected after the host has been killed.] Oral sucker $2.3 \mathrm{~mm}$ in diameter by $2 \mathrm{~mm}$ deep, subterminal in position; acetabulum $1.8 \mathrm{~mm}$ in diameter by 1.6 $\mathrm{mm}$ deep, according to Odhner $(1.3 \mathrm{~mm}$ in diameter, according to Braun, 1902b), situated a little more than one-third of the body length from the anterior end $(28 \mathrm{~mm}$ from oral sucker, according to Lönnberg). Prepharynx short; pharynx $1.5 \mathrm{~mm}$ long by $950 \mu$ wide $(700 \mu$ wide, according to Braun); esophagus very short; intestinal ceca extend to posterior end of body and are provided with median and lateral dendritic diverticula. The anteriorly directed cecal appendages extend to the level of the middle of the pharynx, each being provided with four lateral diverticula. Excretory vesicle tubular and extending to level of ovary. Genital pore preacetabular; cirrus pouch club shaped, containing a large seminal vesicle and an unarmed cirrus $3 \mathrm{~mm}$ to $4 \mathrm{~mm}$ long. Testes branched, tandem in position, and situated in the posterior half of the body. Ovary star shaped, situated immediately cephalad of the anterior testis, slightly to right of median line. Laurer's canal present; seminal receptacle (?). The vitellaria consist of quadrangular groups of follicles extending both dorsally and ventrally from the level of the pharynx to the posterior end of body. According to Braun, the vitelline ducts consist of a long, slender, anterior duct, which bifurcates to form two lateral ducts that extend to a short distance caudad of ovary where they join the transverse ducts, and of a shorter, unpaired, posterior duct which bifurcates to form anterior lateral ducts which are sometimes connected by transverse anastomoses; the transverse ducts are formed by the union of the anterior and posterior lateral ducts. Uterus convoluted and terminating in a well-developed vagina, which opens into the genital sinus near the male genital aperture. Eggs $120 \mu$ long by $75 \mu$ wide, triangular in cross section.

Hosts.-Balaenoptera acutorostrata (=B. rostrata), B. borealis, and Balaena mysticetus.

Location.-Liver.

Distribution.-Europe. 
Genus ZALOPHOTREMA Stunkard and Alvey, 1929

Generic diagnosis.-Campulinae: Body flattened, somewhat attenuated posteriorly and rounded anteriorly. Oral sucker terminal, larger than acetabulum. Intestinal ceca as in Campula; posterior ceca without anal openings. Excretory pore terminal; excretory vesicle tubular and extending to ovary. Cirrus pouch extending caudad of ovary; cirrus unarmed. Ovary indented but not lobed, pretesticular and slightly to right of median line; seminal receptacle absent; Laurer's canal present. Vitellaria as in Campula. Uterus coiled. Eggs with thickening at posterior pole, circular in cross section. Parasites of pinnipeds.

Type species.-Zalophotrema hepaticum Stunkard and Alvey, 1929.

ZALOPHOTREMA HEPATICUM Stunkard and Alvey, 1929

Plate 3, Figures 13,14

Description.-Zalophotrema: Body elongate and flattened dorsoventrally, 11 to $13 \mathrm{~mm}$ long by 3 to $3.6 \mathrm{~mm}$ wide, and from $600 \mu$ to $1 \mathrm{~mm}$ thick, the thickness decreasing abruptly immediately caudad of testes. Cuticle armed with spines, which vary from $14 \mu$ to $35 \mu$ in length. Oral sucker $700 \mu$ to $800 \mu$ long by $800 \mu$ to $1 \mathrm{~mm}$ wide; oral opening slightly subterminal. Acetabulum $570 \mu$ to $620 \mu$ in diameter, situated one-fifth to one-sixth of the body length from the anterior end. Pharynx piriform, $550 \mu$ to $600 \mu$ long by $380 \mu$ to $420 \mu$ wide. The digestive system bifurcates a short distance caudad of pharynx into two laterally directed branches, each of which bifurcates into a short anterior and a long posterior cecum; the anterior ceca terminate near the anterior end of pharnyx; the posterior ceca are provided with many median and lateral diverticula, and terminate near the posterior end of the body. Excretory pore terminal; excretory vesicle extending anteriorly as a simple sac to the region of the ootype. Cirrus pouch relatively weakly developed, extending from genital pore to level of ovary, according to Stunkard and Alvey (1930), and containing a coiled seminal vesicle, prostate cells, and an unarmed cirrus. Testes large and deeply lobed, tandem in position, and occupying the equatorial third of body. Ovary lobed, $500 \mu$ long by $1 \mathrm{~mm}$ wide, situated at caudal end of anterior third of body; Mehlis's gland posterior and dorsal to ovary; seminal receptacle absent; Laurer's canal present. The vitellaria consist of masses of follicles, which extend in the lateral areas of the body from the level of the pharynx to the posterior end; they tend to be dorsal in position in the anterior part of body, almost meeting in the median line cephalad of genital pore, while caudad of testes they are both dorsal and ventral in position and invade the median 
field. The uterus consists of masses of coils filling the central part of body from the ovary to the acetabulum. The vagina is about one-half the length of the cirrus pouch. Eggs oval, $68 \mu$ to $79 \mu$ long by $43 \mu$ to $52 \mu$ wide, thickened at posterior pole and circular in cross section.

Host.-Zalophus californianus.

Location.-Bile ducts.

Distribution.-North America-United States (New York Aquarium and National Zoological Park, Washington, D. C.).

Remarks.-The foregoing description is slightly modified from that given by Stunkard and Alvey (1930).

Four specimens (U.S.N.M. Helm. Coll. No. 29731) of what appear to be this species were collected, March 17, 1930, from the liver of a specimen of Zalophus californianus, which died in the National Zoological Park, Washington, D. C. These specimens agree in all essential characters with the description given by Stunkard and Alvey except as regards the branching of the anterior ceca and in the length of the cirrus pouch. As regards the anterior ceca, Stunkard and Alvey state that "each of the anterior branches gives off two or three diverticula," but in the specimens at the writer's disposal no such diverticula were found. Two of the specimens showed a slight irregularity in the diameter of these ceca, but this appeared to be due to distention with ingesta. The cirrus pouch is described by Stunkard and Alvey as extending caudally to the level of the ovary, but in the writer's specimens this structure was found to extend to about midway between the posterior margin of the acetabulum and the anterior margin of the ovary. These differences, however, appear too slight to warrant considering the possibility of the writer's specimens representing a species distinct from $Z$. hepaticum.

\section{Genus ORTHOSPLANCHNUS Odhner, 1905}

Generic diagnosis.-Campulinae: Body elongated and slightly flattened; cuticle covered with pointed spines. Intestinal ceca without lateral or median diverticula. Genital pore preacetabular; cirrus pouch long and pestle shaped, extending beyond posterior margin of acetabulum; cirrus armed with strong pointed spines. Testes with indented margins, postequatorial and tandem in position. Ovary without lobes; seminal receptacle very small; Laurer's canal present. Vitellaria profusely developed, the follicles being distributed both dorsally and ventrally from region of pharynx to posterior end of body. Uterus with few coils; vagina well developed and lined with strong pointed spines. Eggs triangular in cross section. Parasites of pinnipeds.

Type species.-Orthosplanchnus arcticus Odhner, 1905. 
1. Body almost cylindrical; ventrally the vitelline follicles encroach on the testicular and uterine fields but do not extend anteriorly as far as pharynx fraterculus (p. 16).

Body somewhat flattened; ventrally the vitelline follicles do not encroach on testicular and uterine fields but extend anteriorly beyond level of posterior end of pharynx arcticus (p. 15).

ORTHOSPLANCHNUS ARCTICUS Odhner, 1905

Plate 4, Figures 17,18

Description.-Orthosplanchnus: Body slightly flattened, $3.5 \mathrm{~mm}$ to $7 \mathrm{~mm}$, usually $4.5 \mathrm{~mm}$ to $6 \mathrm{~mm}$ long by $850 \mu$ to $1.15 \mathrm{~mm}$ wide, tapering toward both ends, the posterior part of body being slightly more attenuated than the anterior part. Cuticle spiny throughout, the spines on the anterior part of body being about $40 \mu$ long, while those at both ends are somewhat smaller. Oral sucker $480 \mu$ to $600 \mu$ in diameter, subterminal in position; acetabulum $450 \mu$ to $530 \mu$ in diameter, situated about one-fourth of body length from anterior end. Prepharynx about $200 \mu$ long, pharynx about $400 \mu$ long by $300 \mu$ wide, esophagus $120 \mu$ to $150 \mu$ long. Intestine with short anteriorly directed ceca, one on each side, which extend to level of anterior end of pharynx, and long posterior ceca, which extend to end of body; both the anterior and posterior ceca are simple and without diverticula. Excretory pore terminal; excretory vesicle simple and tubular, and extending anteriorly to level of anterior margin of anterior testis. Genital aperture preacetabular, median; genital sinus spacious. Cirrus pouch pestle shaped and extending caudally to about midway between acetabulum and anterior testis (about two-fifths of the distance from acetabulum to ovary, according to Cooper, 1921); seminal vesicle more or less spherical and about $250 \mu$ in diameter when filled with sperms, more tubelike when empty; pars prostatica cylindrical, $170 \mu$ to $200 \mu$ long, and set off from the seminal vesicle by a sharp constriction; ejaculatory duct about the same length as pars prostatica; cirrus protrusible and spiny, the spines $40 \mu$ to $45 \mu$ long by $7 \mu$ wide at their bases and inserted into a basai disk $15 \mu$ to $19 \mu$ in diameter by $12 \mu$ thick. Testes elongated oval in shape, with indented margins; the anterior testis is usually slightly smaller than the posterior; they are tandem in position and situated in the anterior half of the posterior part of the body. Ovary entire, transversely oval in shape, situated cephalad of anterior testis and to the right of the median line; seminal receptacle very small; Laurer's canal present. Vitellaria profusely developed and extending both dorsally and ventrally of intestinal ceca from the level of the pharynx to the posterior end of the body; anterior to 
acetabulum the follicles form a transverse dorsal band across body; ventrally the follicles do not encroach on the testicular and uterine fields; caudad of the testes the follicles coalesce in the median line and completely fill the posttesticular zone. The uterus extends anteriorly from Mehlis's gland in transverse loops to the acetabulum, where it terminates in a well-developed vagina, the cuticular lining of which is armed with spines similar to those of the cirrus. Eggs $91 \mu$ to $100 \mu$ long by $54 \mu$ to $58 \mu$ wide, triangular in cross section, and having a thickened posterior pole.

Hosts.-Erignathus barbatus (= Phoca barbata); Phoca hispida.

Location.-Gall bladder and liver.

Distribution.-Europe (west coasts of Greenland and Spitsbergen) ; North America (Canada-Bernard Harbor, Northwest Territories-according to Cooper, 1921).

ORTHOSPLANCHNUS FRATERCULUS Odhner, 1905

Plate 4, Figure 19

Description.-Orthosplanchnus: Body almost cylindrical, $3 \mathrm{~mm}$ to $4 \mathrm{~mm}$ long by $500 \mu$ to $600 \mu$ wide. Cuticular spines more abundant than in $O$. arcticus. Oral sucker $370 \mu$ to $440 \mu$ in diameter; acetabulum $400 \mu$ to $500 \mu$ in diameter. Pharynx $300 \mu$ to $330 \mu$ long by $200 \mu$ wide; esophagus $220 \mu$ long. Cirrus pouch as in $O$. arcticus. Testes deeply indented. Vitellaria do not unite to form a dorsal band anterior to acetabulum, and ventrally they encroach on the testicular and uterine fields. Other characters as in O. arcticus.

Hosts.-Odobenus rosmarus; Erignathus barbatus.

Location.-Gall bladder.

Distribution.-Europe (Spitsbergen).

\section{Genus SYNTHESIUM Stunkard and Alvey, 1930}

Generic diagnosis.-Campulinae: Body long and slender. Suckers of equal size. Digestive system as in Campula. Cirrus pouch long and slender, inclosing seminal vesicle, pars prostatica, and spiny cirrus; testes deeply lobed as in Lecithodesmus. Ovary spherical, pretesticular; vitellaria consist of small, grapelike clusters of follicles and do not extend anteriorly as far as acetabulum; uterus with few coils; vagina lined with spines. Eggs with polar thickening. Parasitic in intestine of cetaceans.

Type species.-Synthesium tursionis (Marchi, 1873).

SYNTHESIUM TURSIONIS (Marchi, 1873), new combination

Plate 5, Figures 20-21

Synonyms.-Distomum tursionis Marchi, 1873, p. 304; Distomum longissimum Poirier, 1886, pp. 29-30, not D. longissimum von Linstow, 
1896; D. (Dicrocoelium) tursionis (Marchi, 1873) Parona, 1896, p. 162.

Description.-Synthesium: Body whitish, $20 \mathrm{~mm}$ long by $1.5 \mathrm{~mm}$ wide, flattened; cuticle spiny. Suckers equal in size, $800 \mu$ in diameter; acetabulum situated $3 \mathrm{~mm}$ to $4 \mathrm{~mm}$ caudad of oral sucker. Prepharynx $1 \mathrm{~mm}$ long; pharynx $720 \mu$ long by $300 \mu$ wide; intestinal ceca as in Brachycladium (=Campula), according to Odhner (1926). Genital aperture preacetabular; cirrus pouch long and tubular, and containing the seminal vesicle, a long slender pars prostatica, and cirrus (cirrus as in Orthosplanchnus, according to Odhner). Testes as in Lecithodesmus, according to Odhner; anterior testis with five lobes and posterior with six lobes, situated in posterior third of body, according to Poirier. Ovary small, almost spherical, pretesticular, and situated near the equator of body; Mehlis's gland a little larger than ovary. Vitellaria well developed and consisting of small grapelike clusters of follicles; they extend from a short distance cephalad of ovary to the posterior end of body. Uterus sinuous; vagina as in Orthosplanchnus. Eggs oval, $56 \mu$ long by $33 \mu$ wide, with thickening at posterior pole.

Host.-Delphinus tursio (probably =Tursiops truncatus).

Location.-Intestine.

Distribution.-Europe.

Remarks.-This description is taken largely from that given by Poirier (1886) for Distomum longissimum. The description given by Marchi (1873) for D.tursionis is very incomplete and the figure accompanying it is very sketchy. Parona (1896) restudied specimens from Marchi's original material and pointed out that D. tursionis Marchi and D. longissimum Poirier were identical, but added nothing to the original descriptions. Odhner (1926) reported that this species had the digestive tract of Brachycladium (=Campula), the lobed testes of Lecithodesmus, and the characteristic copulatory organs (charakterischen Endapparate der Geschlechtswege) of Orthosplanchnus, and suggested that it might be included in the latter genus. Recently Stunkard and Alvey (1930) proposed the genus Synthesium for this species. The writer is in accord with this action, since the inclusion of this species in the genus Orthosplanchnus, or in any of the related genera, would necessitate extensive revision of the diagnoses of these groups; this is regarded as inadvisable until more species have been described.

\section{HADWENIUS, new genus}

Generic diagnosis.-Campulinae: Body very long and slender, cylindrical, suckers close together; oral sucker slightly larger than acetabulum. Cuticle of anterior part of body spiny. Intestinal ceca without diverticula. Excretory vesicle tubular, extending anteriorly 
to near posterior margin of ovary. Cirrus pouch pestle shaped, extending caudad of acetabulum; cirrus spiny as in Orthosplanchnus. Testes oval, tandem in position, situated in anterior fourth of body. Ovary transversely oval, pretesticular; seminal receptacle absent; Laurer's canal present. Vitellaria composed of rosette masses of radiating cords of follicles, which extend from vicinity of anterior testis to posterior end of body. Uterus with few coils confined to intercecal space between ovary and acetabulum; vagina well developed, unarmed. Eggs triangular in cross section, slightly thickened at posterior pole. Parasites of cetaceans.

Type species.-Hadwenius seymouri, new species.

HADWENIUS SEYMOURI, new species

Plate 6, Figures 23-25

Description.-Hadwenius: Body slender, $27 \mathrm{~mm}$ to $60 \mathrm{~mm}$ long by $1.5 \mathrm{~mm}$ to $2 \mathrm{~mm}$ wide, and almost circular in cross section. The cuticle of the interior part of the body is spiny, the spines being about $27 \mu$ long by $7 \mu$ wide and arranged in alternating transverse rows; they are deep-set in the cuticle so that only the tips project above the surface. The rows of spines are close together in the region immediately caudad of the oral sucker, but become farther apart as they approach the region of the anterior testis, where they disappear completely. The oral sucker is cup shaped, $1.8 \mathrm{~mm}$ to $2 \mathrm{~mm}$ long by $1.7 \mathrm{~mm}$ to $2 \mathrm{~mm}$ in diameter, the thickness of the wall being about $190 \mu$; the oral aperture is $540 \mu$ to $900 \mu$ in diameter and slightly subterminal. The acetabulum is transversely oval, $930 \mu$ to $1.2 \mathrm{~mm}$ long by $1.3 \mathrm{~mm}$ to $1.5 \mathrm{~mm}$ wide, and the walls are about $180 \mu$ thick; the distance between the suckers is from $800 \mu$ to $1.6 \mathrm{~mm}$, depending upon the degree of contraction. The length of the prepharynx is variable; in some specimens it is about $810 \mu$ long, while in others the pharynx is drawn into the base of the oral sucker so that the prepharynx is very wide and short. The pharynx is $900 \mu$ to $1 \mathrm{~mm}$ long by $620 \mu$ to $900 \mu$ wide. The esophagus is very short and wide. The intestine is $\mathbf{H}$ shaped as in other members of the subfamily; the ceca are straight and without lateral or median diverticula. The excretory pore is situated at the summit of a papillalike prominence, which projects into a deep pit or depression at the posterior end of the body. The excretory vesicle is similar to that in other members of the subfamily. The genital aperture is situated immediately in front of the anterior margin of the acetabulum; it communicates with a spacious genital sinus. The cirrus pouch is pestle shaped, about $1.8 \mathrm{~mm}$ long by $560 \mu$ wide; it extends caudad a little more than half the distance between the acetabulum and 
ovary. The seminal vesicle is about $830 \mu$ long by $290 \mu$ wide and almost fills the posterior part of the cirrus pouch; pars prostatica slender, about $700 \mu$ long, and separated from the seminal vesicle by a sharp constriction; ejaculatory duct relatively short. The cirrus is protrusible and armed with strong spines. The spines are about $40 \mu$ long and are inserted into a basal disk which is about $16 \mu$ in diameter. Testes oval in shape and situated in the anterior fourth of the body; the anterior testis is $900 \mu$ to $1.5 \mathrm{~mm}$ long by $620 \mu$ to $930 \mu$ wide, and the posterior $1 \mathrm{~mm}$ to $1.6 \mathrm{~mm}$ long by $620 \mu$ to $850 \mu$ wide, the distance between them being $310 \mu$ to $1.2 \mathrm{~mm}$. The ovary is transversely oval, $232 \mu$ to $387 \mu$ long by $465 \mu$ to $590 \mu$ wide, situated a short distance cephalad of the anterior testis and to the right of the median line. Seminal receptacle not observed. Laurer's canal is slender and sinuous, and opens in the mid-dorsal line at the level of the ovary. Mehlis's gland is large and is situated median and dorsal to the ovary. The vitellaria consist of chainlike rows of follicles, which radiate to form rosettelike masses, and extend from the anterior testis to the posterior end of the body; the masses of follicles are distributed on all sides and form a continuous layer beneath the dermomuscular layer of the body. The uterus consists of six or more transverse coils confined to the intercecal field between Mehlis's gland and the acetabulum. The vagina is well developed, unarmed, and about one-half the length of the cirrus pouch; it opens at the base of the genital sinus to the left of the male genital aperture. The eggs are oval, $97 \mu$ long by $52 \mu$ wide, with a short prolongation at the posterior pole, triangular in cross section.

Host.-White whale (Delphinapterus leucas).

Location.--Intestine.

Distribution.-North America (Alaska).

Type specimens.-U.S.N.M. Helm. Coll. No. 30807; paratypes, No. 26157. Collected by Dr. Seymour Hadwen, September 9, 1921, at Golovin, Alaska.

Remarks.-Hadwenius seymouri appears to be more closely related to Synthesium tursionis than to any of the other species of Campulinae. Both are parasites of the intestinal tract of cetaceans and are similar in body form. They differ, however, in two principal characters, which are considered generic, viz, the copulatory organs and distribution of the vitellaria. In Hadwenius seymouri the cirrus is armed but the vagina is not, and the vitelline follicles are arranged in rosettelike masses similar to those in Lecithodesmus, while in Synthesium tursionis both cirrus and vagina are armed and the vitelline follicles are distributed in small grapelike groups. Other differences are present, but these appear to be only of specific value. 
Genus ODHNERIELLA Skrjabin, 1915

Generic diagnosis.-Campulinae: Body flat and ribbonlike; cuticle of preacetabular part of body armed with spines. Oral sucker slightly smaller than acetabulum. Digestive tract without anteriorly directed ceca. Excretory vesicle as in Campula. Cirrus pouch saclike, extending beyond posterior margin of acetabulum; cirrus armed with spines as in Orthosplanchnus; testes entire. Ovary entire, pretesticular. Vitellaria consisting of grapelike masses of follicles, situated laterally and not invading median field, and extending from about midway between ovary and acetabulum to level of termination of ceca. Uterus relatively short; vagina unarmed. Eggs triangular in cross section. Parasites of pinnipeds.

Type species.-Odhneriella rossica Skrjabin, 1915.

ODHNERIELLA ROSSICA Skrjabin, 1915

\section{Plate 5, Figure 22}

Description.-Odhneriella: Body flat and ribbonlike, $9^{\circ} \mathrm{mm}$ long by $760 \mu$ wide at acetabulum; sides of body almost parallel. Cuticle of preacetabular part of body armed with spines. Oral sucker directed ventrally, $500 \mu$ long by $480 \mu$ to $530 \mu$ wide; acetabulum $500 \mu$ long by $680 \mu$ wide, slightly elevated above surface of body, and situated in anterior part of body. Prepharynx 119 $\mu$ long; pharynx $325 \mu$ long by $290 \mu$ wide; esophagus $230 \mu$ long; intestinal ceca simple and extending to posterior end of body; anteriorly directed ceca, characteristic of other members of the subfamily, absent. Excretory pore terminal; excretory vesicle as in other members of the subfamily. Genital pore median, near anterior margin of acetabulum. Cirrus pouch saclike, extending beyond posterior margin of acetabulum; cirrus strong and armed with spines. Testes oval, $935 \mu$ long by $390 \mu$ wide, entire, tandem in position, and situated in the posterior fourth of the anterior half of the body. Ovary globular, $300 \mu$ to $340 \mu$ in diameter, pretesticular. Vitellaria consisting of grapelike masses of follicles distributed along sides of body and extending from about midway between ovary and acetabulum to level of ends of ceca. Uterus short, with few coils, situated in the intercecal field between ovary and acetabulum; vagina straight and unarmed. Eggs oval, $100 \mu$ long by $60 \mu$ wide, thickened at posterior pole, triangular in cross section.

Host.-Odobenus rosmarus.

Location.-Bile ducts.

Distribution.-Europe (Russia). 
Remarks.-The foregoing description, taken from Skrjabin (1915), ${ }^{1}$ was based upon specimens collected by Doctor Starokadomsky, February 8, 1912, in north Russia, near Kaluchinskaya Bay.

\section{Family ECHINOSTOMATIDAE Looss, 1902}

Family diagnosis.-Body more or less elongate, small or very large, usually much flattened anteriorly, less so, or even cylindrical, posteriorly. Oral sucker small and weak, surrounded dorsally and laterally, but not ventrally, by a collarlike fold, bearing one or two rows of spines, which are continued laterally to ventral corners, the corner spines usually large or specialized; acetabulum large and powerful, usually preequatorial and near oral sucker. Cuticle usually spinose, especially anteriorly. Excretory vesicle $\mathrm{Y}$ shaped, with lateral twiglike branches. Pharynx and epithelial "pseudoesophagus" present; intestinal ceca extend to posterior end of body. Genital aperture preacetabular; genital sinus present or absent; cirrus pouch usually present. Testes postequatorial, usually tandem in position. Ovary pretesticular, usually to right of median line; Laurer's canal present. Vitellaria lateral, rarely extending anterior to acetabulum. Uterus in transverse coils, rarely extending beyond intercecal field. Parasites of intestines or bile ducts of vertebrates, especially birds.

Type genus.-Echinostoma Rudolphi, 1809.

\section{Genus ECHINOSTOMA Rudolphi, 1809 (sensu lato)}

Generic diagnosis.-Characters of the family.

ECHINOSTOMA ACANTHOIDES (Rudolphi, 1819) Cobbold, 1860

Synonym.-Distoma acanthoides, Rudolphi, 1819, p. 114.

Description.-Echinostoma: Body elongated and flattened (4 mm to $6 \mathrm{~mm}$ long, according to Dujardin, 1845), divided into a somewhat slender $(271 \mu$ wide) anterior part and a broader $(520 \mu$ wide) posterior part (Dujardin gives the maximum width of the body as $750 \mu$ ) the two portions being united at the level of the acetabulum. Oral sucker $156 \mu$ long by $135 \mu$ wide; acetabulum $375 \mu$ long by $396 \mu$ wide, situated about one-third of the body length from the anterior end. Cephalic collar provided with four spines, $73 \mu$ long, on each ventral lobe, with 16 to 18 smaller spines, $59 \mu$ long, arranged around the margin in a single row, uninterrupted dorsally, and with one small spine,

\footnotetext{
1 The writer is indebted to Dr. R. Ed. Schulz, of the School of Veterinary Medicine, Moscow, for a typewritten copy of Professor Skrjabin's paper, the publication in which this paper appeared being unavailable in this country.
} 
$26 \mu$ long, on each side between the larger spines of the ventral lobes and the smaller marginal spines. Pharynx $145 \mu$ long by $114 \mu$ wide, situated almost immediately caudad of the oral sucker. Testes globular $159 \mu$ in diameter, tandem in position and situated in the posterior part of the body. Vitellaria lateral, not extending anteriorly beyond acetabulum.

Host.-Phoca vitulina.

Location.-Intestine.

Distribution.-Europe (Berlin, Germany).

Remarks.-Rudolphi (1819) reported finding two specimens of this species in the above host in Berlin. Braun (1901a) redescribed this form on the basis of the original material and stated that the specimens were immature. The above description is compiled largely from that given by Braun.

It is not certain that this species belongs to the genus Echinostoma, sensu stricto. The arrangement of the spines of the cephalic collar tends to exclude it from the genus, but the other characters are not sufficiently well described to permit a definite generic assignment at present.

\section{Genus STEPHANOPRORA Odhner, 1902}

Synonyms.-Mesorchis Dietz, 1909a, p. 183; Monitifer Dietz, 1909 a, p. 183.

Generic diagnosis.-Echinostomatidae: Body elongated and subcylindrical. Cuticle of anterior part of body armed with spines. Oral sucker surrounded by a well-developed reniform collar bearing a single row of spines, which is interrupted dorsally by a space about as wide as oral sucker. Acetabulum situated approximately one-fourth of body length from anterior end. Cirrus pouch well developed, containing seminal vesicle, pars prostatica, and a short, strong cirrus. Testes tandem in position, situated near equator of body. Ovary pretesticular. Vitellaria almost filling posttesticular part of body and extending anteriorly to anterior testis. Uterus moderately long and containing relatively few eggs.

Type species.-Stephanoprora ornata Odhner, 1902.

STEPHANOPRORA DENTICULATA (Rudolphi, 1802) Odhner, 1910

Plate 7, Figures 29-30

Synonyms.-Fasciola denticulata Rudolphi, 1802, p. 91; Distoma denticulatum (Rudolphi, 1802) Rudolphi, 1809, p. 424-425; Echinostoma denticulatum (Rudolphi, 1802) Cobbold, 1860, p. 36; Echinostoma (Mesorchis) denticulatum (Rudolphi, 1802) Dietz, 1909a, p. 183; Mesorchis denticulatus (Rudolphi, 1802) Dietz, 1909b, p. 31. 
Description.-Stephanoprora: Body elongated, $2.08 \mathrm{~mm}$ to $2.64 \mathrm{~mm}$ long by $288 \mu$ to $352 \mu$ wide at acetabulum. Cuticle of anterior part of body closely beset with spines arranged in alternating transverse rows; these rows are close together in the region anterior to acetabulum, but caudad of this point they are more widely separated and finally disappear in the region of the anterior testis. Oral sucker subterminal, $74 \mu$ to $92 \mu$ in diameter, surrounded by a well-defined reniform collar, $213 \mu$ to $237 \mu$ wide. The collar bears 22 spines arranged in a single row, which is interrupted dorsally by a space almost as wide as the oral sucker. Four of these spines, two on each ventral lobe, are slightly smaller and more aboral than the marginal spines; they measure $29 \mu$ to $37 \mu$ long by $11 \mu$ to $14 \mu$ wide; the marginal spines are $37 \mu$ to $44 \mu$ long by $11 \mu$ to $15 \mu$ wide. Acetabulum almost circular, $185 \mu$ to $222 \mu$ in diameter, situated $370 \mu$ to $560 \mu$ from anterior end of body. Prepharynx $37 \mu$ long; pharynx $81 \mu$ to $110 \mu$ long by $74 \mu$ wide; esophagus $92 \mu$ to $166 \mu$ long; intestinal ceca slender. Genital pore situated about midway between intestinal bifurcation and anterior margin of acetabulum. Cirrus pouch ovoid, $185 \mu$ to $222 \mu$ long by $48 \mu$ to $129 \mu$ wide, containing a large seminal vesicle, pars prostatica, and short cirrus. Testes tandem in position, situated in equatorial zone; anterior testis globular, $166 \mu$ to $229 \mu$ in diameter; posterior testis ovoid, $203 \mu$ to $259 \mu$ long by $148 \mu$ to $222 \mu$ wide. Ovary transversely oval, $85 \mu$ to $110 \mu$ long by $100 \mu$ to $122 \mu$ wide, situated cephalad of anterior testis and to right of median line. Vitellaria consisting of large follicles and extending from level of posterior margin of anterior testis to near posterior end of body. Uterus short and with few coils. Eggs $74 \mu$ to $77 \mu$ long by $52 \mu$ to $55 \mu$ wide.

Host.-Zalophus californianus.

Location.-Small intestine.
Distribution.-North
America-United States
(Washington, D. C.).

Specimens.-U.S.N.M. Helm. Coll. No. 28147. Collected by E. W. Price, June 1, 1928, from a California sea lion, which died in the National Zoological Park.

\section{Family TROGLOTREMATIDAE Odhner, 1914}

Family diagnosis.-Body compact, more or less flattened ventrally and convex dorsally. Cuticle with pointed spines. Body musculature as well as that of suckers weakly developed. Excretory vesicle $Y$ shaped or tubular. Pharynx present; esophagus short; intestinal ceca extend to near posterior end of body. Genital pore near acetabulum, either immediately in front or behind, median or slightly to the left. Cirrus pouch absent except in Troglotrema; pars prosta- 
tica and seminal vesicle always distinct. Testes opposite each other, equatorial or postequatorial. Ovary usually lobed, dextral, pretesticular; seminal receptacle and Laurer's canal present. Vitellaria usually well developed, exclusively or mostly dorsal, leaving only the median dorsal area of body unoccupied. Uterus either very long, with relatively few loops, or shorter and more convoluted. Parasites of carnivorous mammals and birds, usually occurring in pairs in cystlike cavities.

Type genus.-Troglotrema Odhner, 1914.

\section{Genus PHOLETER Odhner, 1914}

Generic diagnosis.-Troglotrematidae: Body more or less spindle shaped. Cuticle armed with small pointed spines, the spines not in groups. Excretory vesicle $Y$ shaped, the bifurcation occurring in front of testes, and branches extending to acetabulum. Genital aperture at anterior border of acetabulum, slightly to left of median line; genital sinus moderately deep and wide; cirrus pouch absent; pars prostatica short, directed dorsoventrally; seminal vesicle tubelike, undivided, extending under the dorsal surface to near the ovary. Testes elliptical, situated opposite each other a short distance from the posterior end of body. Ovary deeply lobed; seminal receptacle present; Laurer's canal moderately long. Vitellaria strongly developed, dorsal in position, and having a tendency to occur in grapelike bunches. Uterus long and convoluted, occupying entire body width and extending from ovary to genital pore. Parasites of cetaceans.

Type species.-Pholeter gastrophilus (Kossack, 1910) Odhner, 1914.

\section{PHOLETER GASTROPHILUS (Kossack, 1910) Odhner, 1914}

Plate 7, Figure 26

Synonym.-Distomum gastrophitum Kossack, 1910, pp. 118-120.

Description.-Pholeter: Body spindle shaped, $1.5 \mathrm{~mm}$ to $3.33 \mathrm{~mm}$ long by $1.7 \mathrm{~mm}$ to $2.1 \mathrm{~mm}$ wide according to Odhner (1914), or $3.15 \mathrm{~mm}$ to $3.66 \mathrm{~mm}$ long by $1.8 \mathrm{~mm}$ to $2.25 \mathrm{~mm}$ wide according to Kossack (1910), the thickness being about one-third of the width. Oral sucker $170 \mu$ to $200 \mu$ in diameter; acetabulum $250 \mu$ to $300 \mu$ in diameter, situated about one-third of the body length from the anterior end. Pharynx $150 \mu$ to $170 \mu$ in diameter; esophagus of same length as pharynx; intestinal ceca simple and terminating about the middle of testes. Genital pore situated at the anterior margin of acetabulum; cirrus pouch absent; pars prostatica short and directed 
dorsoventrally; seminal vesicle tubelike; undivided. Testes elliptical, situated side by side in the posterior third of the body. Ovary deeply lobed, situated immediately cephalad of testes and slightly to one side of the median line; seminal receptacle moderately large, dorsal to ovary. Vitellaria dorsal and extending from about halfway between intestinal bifurcation and acetabulum to the level of the ends of the ceca. Uterus long and strongly looped, occupying almost the entire width of the body from the ovary to the genital pore; vagina short. Eggs oval, $23 \mu$ to $25 \mu$ long by $14 \mu$ wide.

Host.-Phocaena phocoena (=P. communis).

Location.-Stomach (encysted in the mucosa of the pylorus).

Distribution.-Europe.

\section{Family OPISTHORCHIIDAE Braun, 1901}

Family diagnosis.-Medium-sized to small forms; body elongate, flat, thin, transparent, with weak musculature. Suckers relatively weakly developed. Intestinal ceca simple, extending to posterior end of body. Excretory vesicle $Y$ shaped with long stem and short branches. Genital aperture median, immediately preacetabular; no genital sinus containing suckerlike structures or gonotyls. Cirrus pouch and cirrus absent; seminal vesicle coiled. Testes in postequatorial region, situated more or less obliquely. Ovary pretesticular; seminal receptacle voluminous; Laurer's canal present. Vitellaria lateral of ceca, moderately developed, not reaching posterior end of body. Uterus long, with numerous loops, usually confined to intercecal space between ovary and acetabulum. Eggs small and numerous. Parasites of bile ducts and gall bladder of mammals, birds, fishes, and reptiles.

Type genus.-Opisthorchis R. Blanchard, 1895.

KEY TO SUBFAMHIES OF OPISTHORCHIIDAE

1. Vitellaria and uterus do not extend cephalad of acetabulum.

Opisthorchiinae (p. 25).

Vitellaria and uterus extend cephalad of acetabulum_- Metorchiinae (p. 30).

\section{Subfamily Opisthorchinnae Looss, 1899}

- Subfamily diagnosis-Opisthorchiidae: Excretory pore terminal; stem of excretory vesicle long. Vitellaria do not extend anteriorly beyond level of acetabulum. Uterine coils usually confined to intercecal space and not extending anteriorly beyond acetabulum.

Type genus.-Opisthorchis R. Blanchard, 1895. 
KEY TO GENERA OF OPISTHORCHIINAE OCCURRING IN MARINE MAMMALS

1. Uterine coils extend laterally beyond limits of intestinal ceca.

Cyclorchis (p. 28).

Uterine coils do not extend laterally beyond limits of intestinal ceca

2. Vitellaria divided into two distinct regions by a break at the

level of the ovary

Amphimerus (p. 29).

Vitellaria not divided into two regions Opisthorchis (p. 26).

\section{Genus OPISTHORCHIS R. Blanchard, 1895}

Generic diagnosis.-Opisthorchiinae: Body elongated, flattened, anterior end attenuated, posterior end broader. Cuticle generally smooth, without spines. Excretory vesicle $\mathbf{Y}$ shaped, with $\mathbf{S}$-shaped stem and short branches. Cirrus pouch absent; testes usually lobed, situated in posterior part of body and placed obliquely to the long axis of the body. Ovary simple or lobate, pretesticular; seminal receptacle prominent, postovarial; Laurer's canal present. Uterus with numerous transverse loops confined to intercecal field, not extending anteriorly beyond acetabulum. Vitellaria moderately developed, extracecal, not extending anteriorly beyond level of acetabulum or posteriorly beyond level of ovary. Parasites of bile ducts of mammals, birds, and fishes.

Type species.-O pisthorchis felineus (Rivolta, 1884) R. Blanchard, $1895=$ O. tenuicollis (Rudolphi, 1819).

\section{OPISTHORCHIS TENUICOLLIS (Rudolphi, 1819) Stiles and Hassall, 1896}

\section{Plate 7, Figures 27, 28}

Synonyms.-Distoma tenuicollis Rudolphi, 1819, p. 93 ; D. conus Gurlt, 1831, p. 193, not Creplin, 1870; D. lanceolatum von Siebold, 1836, p. 113, not Rudolphi, 1803; D. felineum Rivolta, 1884, pp. 20 28; D. viverrini Poirier, 1886, pp. 116-130; Opisthorchis felineus (Rivolta, 1884) R. Blanchard, 1895, p. 217; O. viverrini (Poirier, 1886) Stiles and Hassall, 1896, p. 155 ; O. tenuicollis-felineus Looss, 1899, p. 678.

Description.-Opisthorchis: Body flat, $6.5 \mathrm{~mm}$ to $8.5 \mathrm{~mm}$ long by $2.1 \mathrm{~mm}$ to $2.2 \mathrm{~mm}$ wide, anterior end somewhat more attenuated than posterior end. Cuticle smooth and without spines. Oral sucker subterminal, $320 \mu$ to $340 \mu$ in diameter; acetabulum $260 \mu$ to $320 \mu$ long by $300 \mu$ to $360 \mu$ wide, situated $1.4 \mathrm{~mm}$ to $1.6 \mathrm{~mm}$ from the anterior end of body. Pharynx ovoid to piriform in shape, $200 \mu$ long by $140 \mu$ to $160 \mu$ wide; esophagus $80 \mu$ to $140 \mu$ long; intestinal ceca slender and extending to near posterior end of body, the left cecum being slightly shorter than the right. Excretory vesicle $Y$ shaped, with a long sigmoid stem and short branches. Genital aperture immediately cephalad of acetabulum. Seminal vesicle more or less 
spirally coiled and free in parenchyma, situated posterior to acetabulum and to the right of the median line. Testes lobed and situated in the posterior third of body; the anterior testis has four lobes and measures $500 \mu$ to $600 \mu$ long by $660 \mu$ to $700 \mu$ wide; the posterior testis has five lobes and is $540 \mu$ to $700 \mu$ long by $680 \mu$ to $700 \mu$ wide. Ovary more or less trilobed, $160 \mu$ to $200 \mu$ long by $400 \mu$ to $440 \mu$ wide, situated slightly to right of median line and about $400 \mu$ to $440 \mu$ cephalad of anterior testis. Mehlis's gland diffuse, dorsad and cephalad of ovary; seminal receptacle large, somewhat ovoid or retort shaped, situated to the right and caudad of ovary; Laurer's canal long and slender. Vitellaria extracecal, each one composed of eight poorly defined groups of follicles which extend from a short distance caudad of acetabulum to level of ovary. Uterus with closely packed loops confined to intercecal field between ovary and acetabulum. Eggs oval, $27 \mu$ to $31 \mu$ long by $13 \mu$ to $15 \mu$ wide.

Hosts.-Erignathus barbatus (=Phoca barbata), Hatichoerus grypus, Phocaena phocoena (=Delphinus phocoena=Phocaena communis), Gulo borealis, Felis viverrina, domestic cat, dog, and man.

Location.-Liver (bile ducts).

Distribution.-Europe; Asia (Siberia).

Remarks.-The above description is based upon specimens (U.S.N.M. Helm. Coll. No. 3357) labeled "Opisthorchis felineus (Riv.), Halichoerus grypus, Konigsberg Thiergarten, collected and determined by Mühling," which were donated to the helminthological collection by Prof. Max Lühe, June, 1902. These specimens are considerably smaller than the measurements given by various authors for $C$. tenuicollis, but so far as can be determined from the literature, this species exhibits considerable variation as regards size.

Whether Opisthorchis tenuicollis and O. felineus are identical species appears to be a moot question. Braun (1893) stated: "So reiht sich Dist. tenuicolle Rud. aus Phoca barbata dem Dist. felineum Riv. und verwandten Arten an." Mühling (1896, 1898a, and 1898b) was convinced of their morphological identity, as was Looss (1899). Barker (1911) noted that there was a lack of specific characters that would definitely separate the two species. Morgan (1927) also states that several species of the genus, including $O$. tenwicollis and $O$. felineus, are very similar and of questionable validity, and points out that widely different hosts, when feeding on the same intermediate host, may become infested with the same species of fluke. After studying the descriptions and figures of $O$. tenuicollis and $O$. felineus, the writer is convinced that they are the same morphological species and should no longer be regarded as distinct. There also appears to be no good reason for considering $O$. viverrini as valid, especially since the figure given by Fuhrmann (1928) shows that the uterine 
coils are more closely packed than those figured by Poirier (1886) for this species, the distribution of the uterine coils being essentially the only character by which this species could be differentiated from $O$. tenuicollis ( $=O$. felineus). It is also possible that $O$. entzi, described by von Ratz (1900) from the gall bladder of Ardea purpurea, and $O$. geminus, described by Looss (1896) from the liver of Milvus parasitious, are species identical with $O$. tenuicollis, since the characters given fall within the range of variation exhibited in the latter species.

It appears that in the case of $O$. tenuicollis there is a lack of host specificity, as is also the case for Cryptocotyle lingua and certain other trematodes.

\section{Genus CYCLORCHIS Lühe, 1908}

Generic diagnosis.-Opisthorchiinae: Body more or less spindle shaped, the maximum width being near the equator. Cuticle without spines. Suckers about equal in size. Digestive tract and excretory vesicle as in Opisthorchis. Testes globular, situated in posterior fourth of body. Ovary and adjacent structures as in Opisthorchis. Vitellaria lateral, situated in posterior half of body, but not extending caudally beyond level of seminal receptacle. Uterine coils loosely arranged and extending laterally beyond limits of ceca.

Type species.-Cyclorchis amphileucus (Looss, 1896) Lühe, 1908.

CYCLORCHIS CAMPULA (Cobbold, 1876) Lühe, 1908

Plate 8, Figure 31

Synonyms.-Distoma campula Cobbold, 1876, p. 40; Metorchis campula (Cobbold, 1876) Looss, 1899, p. 565; Opisthorchis campula (Cobbold, 1876) Looss, 1899, p. 559.

Description.-Cyclorchis: Body elliptical, about $3 \mathrm{~mm}$ long by 1 $\mathrm{mm}$ wide, slightly more attenuated anteriorly than posteriorly. Oral sucker subterminal; acetabulum about the same size as oral sucker, situated about one-fourth of the body length from the anterior end. Esophagus short; intestinal ceca relatively wide and sinuous, extending to posterior end of body. Genital pore preacetabular; testes ovoid and situated diagonally to the long axis in the posterior fourth of body. Ovary small; seminal receptacle large. The body which Cobbold says is "apparently the ovary" is probably the distended seminal receptacle, and the smaller body immediately in front of it is probably the ovary. Vitellaria (?). The uterus passes posteriorly and forms a transverse loop between the ovary and testes, and then passes anteriorly in transverse loops which extend laterally be- 
yond the inner limits of the ceca. Eggs " $1 / 1000$ of an inch from pole to pole by $1 / 2100$ inch in breadth."

\section{Host.-Platanista gangetica.}

Location.-Bile ducts.

Distribution.-Asia (India).

Remarks.-The foregoing description is taken largely from Cobbold's (1876) figure of Distoma campula. The description which he gives for this form is very incomplete, and almost no measurements are given. Cobbold confused this species with Campula oblonga, a species which he had described earlier from Phocaena phocoena $(=P$. communis $)$, his identification being based largely on the zigzag course of the intestinal ceca. The species from Platanista gangetica is unquestionably an opisthorchid and has been placed in the genus Cyclorchis by Lïhe (1908) as species inquirenda. The disposition of the reproductive organs, so far as they have been figured by Cobbold, is strikingly similar to that in $C$. amphileucus so that there appears to be good reason for including it in the same genus.

\section{Genus AMPHIMERUS Barker, 1911}

Generic diagnosis.-Opisthorchiinae: Body elongated and flattened, anterior end attenuated. Cuticle frequently covered wholly or in part with small spines. Excretory vesicle as in Opisthorchis. Cirrus pouch and cirrus absent; testes in posterior part of body, simple or lobate, situated diagonally to long axis of body. Ovary anterior to testes, simple or lobate; seminal receptacle well developed; Laurer's canal present. Vitellaria well developed, lateral of intestinal ceca, divided into two distinct regions by a break opposite the ovary, not extending anteriorly beyond the acetabulum, but frequently extending posteriorly to or beyond the posterior testis. Uterus anterior to ovary as in Opisthorchis; the coils may extend laterally beyond the inner limits of the ceca. Parasites of the bile ducts of mammals, birds, and reptiles.

Type species.-Amphimerus ovatis Barker, 1911.

AMPHIMERUS LANCEA (Diesing, 1850) Barker, 1911

Plate 8, Figures 32-33

Synonyms.-Distomum lancea Diesing, 1850, p. 334; Opisthorchis lancea (Diesing, 1850) Braun, 1901c, p. 897.

Description.-Amphimerus: Body lanceolate, $5.5 \mathrm{~mm}$ to $12.5 \mathrm{~mm}$ long by $1 \mathrm{~mm}$ to $2.8 \mathrm{~mm}$ wide; anterior end conical and shorter than the flattened posterior portion; margins of posterior portion serrated. Oral sucker subterminal, $330 \mu$ to $360 \mu$ by $510 \mu$ to $660 \mu$; acetabulum $510 \mu$ to $1.2 \mathrm{~mm}$ in diameter, situated one-third of the body length 
from the anterior end. Genital pore preacetabular and median in position. Testes spherical or lobed, slightly oblique in position and situated in the posterior part of the body. Ovary biscuit shaped; seminal receptacle generally spindle shaped, situated caudad and to the right of the ovary; Mehlis's gland indistinct. Vitellaria lateral to intestinal ceca, consisting of eight groups of follicles on each side of body divided into two regions by a break between the fourth and fifth groups, and extending from a short distance caudad of the acetabulum to the ends of the intestinal ceca. Uterus consisting of transverse coils which extend intercecally from the ovary to the acetabulum. Eggs oval, $29 \mu$ to $33 \mu$ long by $12 \mu$ to $14 \mu$ wide.

Hosts.-Delphinus tacuschi (probably=Sotalia tucuxi), Orcaella brevirostris.

Location.-Not given; probably bile ducts.

Distribution.-South America (Brazil-Barra do Rio Negro), (?) Asia (India).

Cobbold (1876) reported what he thought was this species from Orcaella brevirostris, the specimens upon which the report was based having been collected in "the North-eastern Province of India" by Dr. John Anderson, superintendent of the Indian Museum, Calcutta. The character which apparently caused Cobbold to regard the form from India as the same as that from Brazil was the "irregularly serrated" margin of the body, since he states: "I know of no other trematode possessing these sinuosities." The description and figure which he gave are quite different than those given by Diesing (1855) and by Weski (1900). The writer doubts whether the form which Cobbold calls Distoma lancea is the same as Diesing's species, but on account of the incompleteness of his description and figure, no opinion is expressed as to its probable affinities.

Subfamily Metorchinnae Lühe, 1909

Subfamily diagnosis.-Opisthorchiidae: Excretory pore ventral; stem of excretory vesicle usually short, ventral to testes. Vitellaria extend cephalad of acetabulum. Uterine coils frequently overlap ceca and extend cephalad of acetabulum.

Type genus.-Metorchis Looss, 1899.

KEY TO GENERA OF METORCHIINAE OCCURRING IN MARINE MAMMALS

1. Posterior end truncate and suckerlike. Pseudamphistomum (p. 31).

Posterior end rounded Metorchis (p. 30).

\section{Genus METORCHIS Looss, 1899}

Generic diagnosis.-Metorchiinae: Body rounded posteriorly and attenuated anteriorly. Cuticle usually covered with spines. Intestinal ceca extend to posterior end of body. Testes large, usually 
lobed, and more or less obliquely placed, and almost filling posterior part of body. Ovary, Mehlis's gland, seminal receptacle, and Laurer's canal as in Opisthorchis. Vitellaria compact and extending anteriorly beyond acetabulum. Uterine coils often extend extracecally and preacetabular. Parasitic in gall bladder and bile ducts of mammals and birds.

Type species.-Metorchis albidus (Braun, 1893) Looss, 1889.

METORCHIS ALBIDUS (Braun, 1893) Looss, 1899

Plate 8, Figure 34

Synonyms.-Distomum albidum Braun, 1893, pp. 347-355; D. (Dicrocoelium) albidum Braun, 1893, p. 353; Opisthorchis albidus (Braun, 1893) Railliet, 1896, p. 160.

Description.-Metorchis: Body spatulate, $1.6 \mathrm{~mm}$ to $2.2 \mathrm{~mm}$ long by $800 \mu$ to $1 \mathrm{~mm}$ wide; anterior part of body narrower than the flat posterior part. Cuticle covered with small spines. Oral sucker subterminal, $200 \mu$ to $240 \mu$ in diameter; acetabulum $200 \mu$ in diameter and situated $600 \mu$ to $900 \mu$ from the anterior end of the body. Pharynx ovoid, $75 \mu$ to $90 \mu$ long by $47 \mu$ to $85 \mu$ wide; esophagus $28 \mu$ long; intestinal ceca extend to posterior end of body. Genital aperture preacetabular; seminal vesicle relatively short. Testes lobed, oblique in position, the left testis anterior to right, and situated in the posterior part of the body; the anterior testis is $300 \mu$ to $340 \mu$ long by $300 \mu$ to $380 \mu$ wide, and the posterior $320 \mu$ long by $380 \mu$ wide. Ovary somewhat triangular in shape, $100 \mu$ to $180 \mu$ long by $140 \mu$ to $180 \mu$ wide, situated a short distance in front of anterior testis. Seminal vesicle large and situated posterolateral of ovary; Mehlis's gland diffuse. Vitellaria lateral and extending from near level of intestinal bifurcation to level of ovary. Uterus greatly convoluted and occupying the greater part of the intervitellarian field from the ovary to a short distance cephalad of acetabulum. Eggs $27 \mu$ to $32 \mu$ long by $13 \mu$ to $16 \mu$ wide.

Hosts.-Halichoerus grypus, Felis domestica, Vulpes vulpes, and Canis familiaris.

Location.-Gall bladder and bile ducts.

Distribution.-Europe.

\section{Genus PSEUDAMPHISTOMUM Lühe, 1908}

Generic diagnosis.-Metorchiinae: Body conical in shape, anterior end pointed; posterior end truncate and surrounded by a ridge giving it a suckerlike appearance. Cuticle beset with fine spines. Excretory pore in center of posterior suckerlike structure. Intestinal ceca slightly sinuous, extending to posterior end of body. Genital 
pore preacetabular; cirrus pouch and cirrus absent; seminal vesicle convoluted, free in parenchyma. Testes in posterior third of body, placed slightly obliquely to long axis of body. Ovary median in position, situated about midway between anterior border of testes and acetabulum; seminal receptacle voluminous, postovarial. Vitellaria extracecal and consisting of relatively large groups of follicles extending from level of seminal receptacle to level of genital pore or slightly beyond. Uterus greatly convoluted, extending laterally over ceca and anteriorly beyond acetabulum. Parasites of bile ducts of mammals.

Type species.-Pseudamphistomum truncatum (Rudolphi, 1819) Lühe, 1908.

PSEUDAMPHISTOMUM TRUNCATUM (Rudolphi, 1819) Lühe, 1908

Plate 8, Figure 35

Synonyms.-Amphistoma truncatum Rudolphi, 1819, p. 91; Distoma conus Creplin, 1825, pp. 50-53; Distomum lanceolatum Mehlis of Diesing, 1858, p. 332; Distoma campanulatum Ercolani, 1875, pp. 432-439; Metorchis truncatus (Rudolphi, 1819) Looss, 1899, p. 565.

Description.-Pseudamphistomum: Body conical, $2 \mathrm{~mm}$ long, anterior end pointed, posterior end truncate and suckerlike. Cuticle thickly and regularly beset with fine spines. Oral sucker $132 \mu$ to $137 \mu$ in diameter; acetabulum about same size as oral sucker and situated slightly preequatorial. Excretory pore situated in the depression of the posterior suckerlike structure. Pharynx $91 \mu$ long; esophagus very short; intestinal ceca slightly sinuous and extending to posterior end of body. Genital aperture preacetabular; seminal vesicle convoluted and free in parenchyma. Testes globular or slightly elliptical, $172 \mu$ to $376 \mu$ long, situated in the posterior third of the body, one slightly in front of the other. Ovary globular, situated about midway between the anterior border of the anterior testis and the acetabulum, usually obscured by the uterine coils; seminal receptacle voluminous, postovarial. Vitellaria situated laterally, chiefly in the middle third of body, each composed of 10 to 12 groups of follicles. Uterus greatly convoluted, occupying the greater part of the body width between testes and acetabulum, and extending somewhat in front of acetabulum. Eggs $29 \mu$ long by $11 \mu$ wide.

Hosts.-Phoca vitulina, P. groenlandica, P. hispida = Halichoerus foetidus, Halichoerus grypus, Gulo boreatis, Felis domestica, Canis familiaris, C. vulpes.

Location.-Bile ducts.

Distribution.-Europe (Germany, Holland, Italy, France). 


\section{Family HETEROPHYIDAE Odhner, 1914}

Famity diagnosis.-Small or very small forms, usually not exceeding $2 \mathrm{~mm}$ in length. Anterior portion of body thinner, usually more slender and more movable than the posterior portion. Surface of body covered with small scalelike spines that become reduced posteriorly and may disappear toward the posterior end of the body. Intestinal ceca simple, usually extending to the posterior end of the body. Genital pore in the immediate neighborhood of the acetabulum; genital ducts usually open into a genital sinus, which may be variously modified and contain a cirruslike body or gonotyl (genital sucker). Acetabulum usually median in position, but may be displaced to the right of the median line; in some instances the acetabulum may be partially or completely atrophied and inclosed in the genital sinus. Cirrus pouch absent. Seminal vesicle well developed, $\mathbf{U}$ or $\mathbf{S}$ shaped, the vas deferens surrounded proximally by a mass of prostatic cells. Testes oval, globular, or slightly lobed, near the posterior end of the body, side by side, or obliquely one in front of the other. Ovary oval, globular or slightly lobed, pretesticular, usually to the right of the median line. Seminal receptacle and Laurer's canal present near the ovary, usually in relation with its posterior border. Vitellaria, located mainly in the lateral fields, may extend anteriorly to or beyond the genital aperture. Uterus usually restricted to the intercecal field between the ovary and genital pore, but may extend to posterior end of body (Galactosomum). Adults parasitic in the intestine of birds and mammals.

Type genus.-Heterophyes Cobbold, 1866.

KEY TO THE GENERA OF HETEROPHYIDAE OCCURRING IN MARINE MAMMALS

1. Acetabulum absent; uterus extending to posterior end of body.

Acetabulum present; uterus not extending caudally beyond anGalactosomum (p. 39). terior border of testes 2 .

2. Acetabulum not contained in the genital sinus; seminal receptacle median and slightly preovarial; vitellaria not extending to acetabulum Phocitrema (p. 38).

Acetabulum contained in the genital sinus; seminal receptacle lateral and postovarial; vitellaria extending cephalad of acetabulum

3. Genital sinus large; genital ducts open into sinus caudad of acetabulum Cryptocoyle (p. 33).

Genital sinus small; genital ducts open into sinus cephalad of acetabulum Apophallus (p. 35).

\section{Genus CRYPTOCOTYLE Lühe, 1899}

Synonyms.-Tocotrema Looss, 1899, p. 585; Hallum Wigdor, 1918, p. 254; Ciureana Skrjabin, 1923, p. 67.

$118893-32-3$ 
Generic diagnosis.-Heterophyidae: Body ovoid to linguiform in shape. Prepharynx very short; esophagus short; intestinal bifurcation nearer to oral sucker than to acetabulum; intestinal ceca extend into posterior end of body and terminate caudad of testes. Acetabulum rudimentary, in anterior wall of the spacious, more or less muscular, genital sinus; genital ducts open into sinus at base of a single papillalike gonotyl; genital aperture postacetabular, in center of genital sinus. Seminal vesicle well developed, curved in a more or less S-like manner, dorsal to uterine coils. Testes near posterior end of body, irregularly oval or slightly lobed, either side by side or the right testis obliquely behind left. Ovary irregularly oval or lobed, situated to right of median line and cephalad of seminal receptacle. Vitellaria fill posttesticular space and extend anteriorly to acetabulum or beyond. Uterus with few loops, confined to intercecal space between ovary and genital sinus.

Type species.-Cryptocotyle concava (Creplin, 1825) Fischoeder, 1903.

CRYPTOCOTYLE LINGUA (Creplin, 1825) Fischeeder, 1903

Plate 9, Figure 36

Synonyms.-Distoma lingua Creplin, 1825, pp. 27-38; Tocotrema lingua (Creplin, 1825) Looss, 1899, p. 586; Distomum macrorhinis MacCallum, 1916, p. 34; Hallum caninum Wigdor, 1918, pp. 254257.

Description.-Cryptocotyle: Body linguiform, $550 \mu$ to $2 \mathrm{~mm}$ long by $200 \mu$ to $900 \mu$ wide. Cuticle covered with scalelike spines, $2 \mu$ to $4 \mu$ long by about $1 \mu$ wide. Oral sucker $66 \mu$ to $110 \mu$ in diameter; prepharynx shorter than pharynx; pharynx $40 \mu$ to $80 \mu$ long by $30 \mu$ to $48 \mu$ wide. Esophagus short, about $40 \mu$ to $60 \mu$ long. Genital sinus $120 \mu$ to $250 \mu$ in diameter, situated near equator of body; acetabulum rudimentary, in anterior wall of sinus. Seminal vesicle long and coiled in an S-like manner, extending caudally to about the level of the anterior border of ovary. Testes irregularly globular or ovoid in shape, $120 \mu$ to $250 \mu$ by $70 \mu$ to $130 \mu$, margins uneven or slightly lobed. Ovary lobed, $70 \mu$ to $120 \mu$ long by $140 \mu$ to $180 \mu$ wide, situated to right of median line; seminal receptacle ovoid in shape and situated caudad of ovary. Vitellaria extend anteriorly beyond acetabulum and caudally to posterior end of body. Uterus confined to intercecal space between ovary and genital sinus. Eggs oval, $49 \mu$ to $50 \mu$ long by $18 \mu$ to $25 \mu$ wide.

Hosts.-Birds (Colymbus auritus, Gavia immer, Larus marinus, L. argentatus, L. fuscus, L. atricilla, Nycticorax nycticorax, Rissa tridactyla, Alca torda, Sterna dougalli, S. hirundo) and mammals 
(Canis familiaris, Vulpes fulva, Phoca vitulina, and Mirounga angustirostris).

Location.-Small intestine.

Distribution.-Europe and North America (United States, Canada).

Remarks.-Cryptocotyle lingua appears to have been reported but twice from pinnipeds. Ransom (1920) reported this species from Phoca vitulina, the report being based upon specimens (U.S.N.M. Helm. Coll. No. 4280) collected by Dr. Albert Hassall, December 21, 1905, at Washington, D. C. MacCallum (1916) described a trematode, Distomum macrorhinis, from specimens collected from an elephant seal, Macrorhinus angustirostris (=Mirounga angustirostris), which died at the New York Aquarium. The writer has examined the specimens upon which MacCallum based his description of $D$. macrorhinis and finds no differences which would warrant regarding this form as a species distinct from Cryptocolyle lingua.

\section{Genus APOPHALLUS Lühe, 1909}

Synonyms.-Rossicotrema Skrjabin and Lindtrop, 1919, p. 40; Cotylophallus Ransom, 1920, p. 529.

Generio diagnosis.-Heterophyidae: Body ovoid to very elongated in shape. Prepharynx short; esophagus long; intestinal bifurcation usually nearer to acetabulum than to oral sucker; intestinal ceca slender, terminating as in Cryptocotyle. Acetabulum relatively well developed, opening into a small, nonmuscular genital sinus; genital ducts open into sinus at the base of two papilliform gonotyls; genital aperture cephalad of acetabulum. Seminal vesicle well developed, C or $\mathbf{S}$ shaped, dorsal to uterine coils. Testes ovoid or globular, situated near posterior end of body, the right usually behind left. Ovary ovoid or globular, situated to right of median line cephalad of seminal receptacle. Vitellaria fill posttesticular space and extend usually to acetabulum or beyond. Uterus as in Cryptocotyle.

Type species.-Apophallus mühlingi (Jägerskiöld, 1899) Lühe, 1909.

KEY TO SPECIES OF THE GENUS APOPHALLUS OCCURRING IN MARINE MAMMALS

1. Esophagus longer than prepharynx; seminal vesicle slender, s shaped; vitelline follicles relatively small, not extending anteriorly as far as pharynx

Esophagus shorter than prepharynx; seminal vesicle wide, C shaped; vitelline follicles relatively large, extending to level of pharynx. zalophi (p. 36). 
Synonyms.-Rossicotrema donicum Skrjabin and Lindtrop, 1919, pp. 41-42; R. simile (Ransom, 1920) Ciurea, 1924, p. 14; Cotylophallus venustus Ransom, 1920, p. 555; C. similis Ransom, 1920, p. 555 .

Description.-Apophallus: Body ovoid to linguiform in shape, $500 \mu$ to $1.14 \mathrm{~mm}$ long by $200 \mu$ to $390 \mu$ wide. Cuticular scalelike spines $4 \mu$ to $7.5 \mu$ long by $1.5 \mu$ to $3 \mu$ wide. Oral sucker $65 \mu$ to $85 \mu$ in diameter; prepharynx very short; pharynx $30 \mu$ to $44 \mu$ in diameter; esophagus slender, bifurcating $135 \mu$ to $265 \mu$ from the anterior end of body; intestinal ceca simple, extending into posterior fourth of body. Acetabulum $45 \mu$ to $58 \mu$ long by $48 \mu$ to $60 \mu$ wide, situated $185 \mu$ to $560 \mu$ from the anterior end of body. Testes oval or globular in shape, $80 \mu$ to $200 \mu$ by $60 \mu$ to $200 \mu$, situated obliquely in extended specimens, more or less opposed in more contracted specimens, and occupying the posterior third of the body. Ovary $65 \mu$ to $140 \mu$ by $40 \mu$ to $120 \mu$, situated $200 \mu$ to $750 \mu$ from the anterior end of body. Seminal receptacle $60 \mu$ to $130 \mu$ wide by $35 \mu$ to $90 \mu$ long, situated between the posteromedian border of the ovary and the anteromedian border of the left testis. Vitellaria well developed, extending from posterior end of body to slightly beyond the bifurcation of the ceca. Uterus with few coils and occupying the intercecal space between anterior border of the left testis and the anterior margin of acetabulum. Eggs $30 \mu$ to $35 \mu$ long by $16 \mu$ to $20 \mu$ wide.

Hosts.-Canis familiaris, Felis domestica, Vulpes lagopus, and Phoca vitulina.

Location.-Small intestine.

Distribution.-Europe and North America (United States).

Remarks.-This description is taken from that of Ransom (1920) for Cotylophallus simitis, the specimens (U.S.N.M. Helm. Coll. No. 4279) upon which the description was based having been collected from the harbor seal by Dr. Albert Hassall, in Washington, D. C., December. 21, 1905. The writer has compared these specimens with specimens from dogs and cats and agrees with Witenberg (1929) that there is no reason for regarding this form as a species distinct from A. donicus ( $=R$. donicum).

APOPHALLUS ZALOPHI, new species

Plate 9, Figure 38

Description.-Apophallus: Body elongated piriform in shape, $435 \mu$ long by $215 \mu$ to $263 \mu$ wide at the level of the ovary. The cuticle is beset with small scalelike spines, $4 \mu$ long by $2 \mu$ wide, arranged in al- 
ternating tranverse rows. Oral sucker slightly subterminal in position, $60 \mu$ to $75 \mu$ in diameter. Prepharynx $30 \mu$ to $33 \mu$ long; pharynx ovoid to spherical in shape, $29 \mu$ to $33 \mu$ wide; esophagus $18 \mu$ long; intestinal ceca relatively wide and extending to near the posterior end of the body, their blind ends being hidden by the testes. The acetabulum is circular, $52 \mu$ to $60 \mu$ in diameter, situated from $235 \mu$ to $259 \mu$ from the anterior end of the body and inclosed in the shallow genital sinus. The genital ducts open into the anterior part of the sinus and two elliptical gonotyls are present, one on each side of the genital aperture. The seminal vesicle is voluminous, more or less C shaped, and lying to the right of the acetabulum; there is a sharp constriction of the vesicle near the level of the posterior margin of the acetabulum which divides it into an anterior piriform part and a posterior globular part. The testes are somewhat triangular in outline, $81 \mu$ to $96 \mu$ by $81 \mu$ to $110 \mu$, and are situated side by side in the posterior fourth of the body. The ovary is more or less triangular in outline, $55 \mu$ to $75 \mu$ by $67 \mu$ to $92 \mu$, situated a short distance cephalad of the right testis. The seminal receptacle is spherical, $44 \mu$ in diameter, and situated dorsal to the ovary and right testis. The vitellaria consist of large, closely packed follicles, which extend from the level of the acetabulum to the level of the anterior margin of the testes; the follicles are distributed over the entire dorsal surface but ventrally they are chiefly lateral except near the intestinal bifurcation where they form a distinct band across the body. The uterus consists of a few loops confined to the intercecal field between the anterior margin of the testes and the genital aperture. The eggs are $33 \mu$ long by $18 \mu$ wide, golden yellow, and slightly piriform in shape.

Host.-Zalophus californianus.

Location.-Small intestine.

Distribution.-North America (United States-National Zoological Park, Washington, D. C.).

Type specimens.-U.S.N.M. Helm. Coll. No. 30808; paratypes, No. 26652 .

Remarks.-Apophallus zalophi is easily distinguished from $A$. donicus, the only species of the genus with which it might possibly be confused, by its size, relative length of the prepharynx and esophagus, and by the distribution of the vitellaria. A. zalophi is on the whole a much smaller species than $A$. donicus and the body is somewhat thicker. The prepharynx is longer than the esophagus in A. zalophi, while in $A$. donicus the reverse is true. The vitelline follicles are relatively larger in $A$. zalophi and extend from the level of the pharynx to the anterior margin of the testes, while in $A$. donicus the follicles extend from about midway between the pharynx and intestinal bifurcation to the posterior end of the body. The arrangement of the genital glands is essentially the same in 
both species; there is, however, a greater tendency for the testes to be opposed in $A$. zalophi than in A. donicus.

\section{Genus PHOCITREMA Goto and Ozaki, 1930}

Generic diagnosis.-Heterophyidae: Body fusiform in shape, cuticle spiny. Oral sucker terminal; acetabulum not inclosed in a genital sinus. Prepharynx shorter than esophagus; intestinal ceca simple and terminating at the anterior border of testes. Genital pore median, immediately preacetabular; testes almost directly opposite each other in posterior part of body; seminal vesicle slender, C shaped, lying free in parenchyma. Ovary oval, pretesticular, situated to right of median line; seminal receptacle large and situated anteromedian of ovary; vitellaria lateral, in posterior half of body; uterus with few transverse coils extending intercecally and extracecally between testes and genital pore.

Type species.-Phocitrema fusiforme Goto and Ozaki, 1930.

Remarks.-Goto and Ozaki (1930) place this genus in the family Opisthorchiidae. It appears to the writer, however, that its affinities are with the Heterophyidae rather than with the Opisthorchiidae, and it is included in this family in spite of the apparent absence of some characters which would definitely determine its systematic position.

PHOCITREMA FUSIFOPME Goto and Ozaki, 1930

Plate 9, Figure 40

Description.-Phocitrema: Body fusiform in shape, $1.16 \mathrm{~mm}$ to $1.4 \mathrm{~mm}$ long by $500 \mu$ to $620 \mu$ wide. Cuticle covered with minute spines. Oral sucker terminal, $80 \mu$ long by $60 \mu$ wide; acetabulum $120 \mu$ in diameter, slightly preequatorial in position. Prepharynx $80 \mu$ long by $60 \mu$ wide; esophagus $120 \mu$ to $180 \mu$ long, bifurcating about midway between pharynx and acetabulum; intestinal ceca terminate at the level of the anterior border of the testes. Genital pore median and situated immediately cephalad of the acetabulum; seminal vesicle elongate, cylindrical, forming a transverse loop between ovary and acetabulum; vas deferens slender, surrounded by glandular cells, expanding at anterior margin of acetabulum to form a bulbous pars prostatica which is surrounded by conspicuous gland cells. Testes oval or reniform in shape, $160 \mu$ to $240 \mu$ by $120 \mu$ to $140 \mu$, situated opposite each other in the anterior part of the posterior fourth of body. Ovary ovoid, about the size of one of the testes, situated to the right of the median line in front of the right testis. Seminal receptacle large, situated obliquely anterior to ovary. Vitellaria consist of five to seven groups of small follicles on each side of the 
posterior half of body. The uterus begins with irregular transverse coils on the left side of ovary, then passes to the right around the ovary and forms two transverse loops caudad of the acetabulum, the loops extending into the extracecal fields; vagina nearly straight, $140 \mu$ long, opening close to the male aperture. Eggs 23 to $28 \mu$ long by 13 to $15 \mu$ wide.

Host.-Phoca hispida.

Location.-Intestine.

Distribution.-Asia (Japan-Hanayashiki Zoological Garden, Tokyo).

\section{Genus GALACTOSOMUM Looss, 1899}

Synonyms.-Microlistrum Braun, 1901b, p. 563; Cercarioides Witenberg, 1929, p. 138.

Generic diagnosis.--Heterophyidae: Body elongated and spindlelike in outline, or expanded anteriorly and more or less cylindrical posteriorly. Prepharynx usually distinct, longer than esophagus; intestinal ceca simple, extending to posterior end of body. Genital aperture situated medially, about one-third of the body length from the anterior end. Genital sinus complicated, containing a spiny, spheroidal, more or less muscular body (gonotyl ?) imbedded in the dorsal wall of the sinus. Seminal vesicle well developed, free in parenchyma, the terminal portion of the vesicle being provided with a muscular wall (expulsor). Testes ovoid, spherical or slightly lobed, tandem or slightly oblique in position, and situated in the posterior half of the body. Ovary spherical or ovoid in shape, situated slightly to the right of the median line and cephalad of the seminal receptacle. Vitellaria extracecal or expanding medially in the posttesticular space, and extending anteriorly as far as the anterior testis or beyond. Uterus with a descending and an ascending limb, both passing between testes.

Type species.-Galactosomum lacteum (Jägerskiöld, 1896) Looss, 1902.

Remarks.-The genus Galactosomum was proposed by Looss (1899) to contain Monostomum lacteum Jägerskiöld. Braun (1901b) proposed the genus Microlistrum to contain three species, Distomum cochleariforme Rudolphi, 1819, D. cochlear Diesing, 1850, and $M$. spinetum Braun, 1901b. Odhner (1910a) pointed out that the structure which Braun interpreted as an acetabulum in the species included in the genus Microlistrum was the same structure as that described by Jägerskiöld (1896) as the "stacheligen Körper" in Galactosomum lacteum. Other similarities were also noted between the two genera. Pratt (1911) gave a redescription of $M$. cochleariforme and showed that the character of the genitalia was essentially 
the same as that described by Jägerskiöld for Monostomum lacteum; on the basis of this similarity he transferred $M$. cochleariforme to the genus Galactosomum, making the two genera synonymous. Travassos (1929) apparently recognizes this arrangement, but Witenberg (1929) regards the two genera as distinct "because of differences in the arrangement of the genital glands." The writer (Price, 1931) has shown that the arrangement of the genital glands is subject to considerable variation within a genus and is a character of no generic importance in the Heterophyidae.

In the same paper, Witenberg proposed a new genus, Cercarioides, as the basis for a new subfamily, Cercarioidinae, the type species, $C$. aharonii, being characterized by having a dilated anterior part of the body set off by a slight constriction from the more cylindrical posterior part. To this new genus, Nazmi (1930) added an additional species, $C$. baylisi. A comparison of the descriptions shows no essential differences between these species and those belonging to the genus Galactosomum. The anterior widening of the body in $C$. aharonii and in $C$. baylisi is only slightly more pronounced than that in $G$. cochleariforme; the arrangement of the genital glands, the course of the uterus, and the terminal portions of the genital ducts also appear to be similar. Therefore, the writer regards Cercarioides Witenberg as a synonym of Galactosomum Looss, the two species $C$. aharonii Witenberg and $C$. baylisi Nazmi becoming G. aharonii (Witenberg) and G. baytisi (Nazmi), respectively.

GALACTOSOMUM ERINACEUM (Poirier, 1886) Bittner and Sprehn, 1928

\section{Plate 9, Figure 39}

Synonyms.-Distomum erinaceum Poirier, 1886, pp. 37-38; Astiotrema erinacea (Poirier, 1886) Stossich, 1904, p. 2.

Description.-Galactosomum: Body elongated, $3 \mathrm{~mm}$ long by $800 \mu$ wide, the anterior half of the body being wider than the posterior half. Cuticle beset with spines, which become less numerous toward the posterior end of body. Oral sucker $300 \mu$ in diameter. Excretory vesicle tubelike, curving between the testes, and extending anteriorly to the vicinity of the ovary. Pharynx small, $17 \mu$ long, the width being almost equal to the length, and situated about $10 \mu$ from the oral sucker. Esophagus short and narrow; intestinal ceca simple and extending to the posterior end of the body. Genital pore $100 \mu$ to $800 \mu$ caudad of the oral sucker; seminal vesicle long, slender, and with muscular walls. Testes globular, $300 \mu$ in diameter, situated diagonally in the posterior third of the body. Ovary globular, $150 \mu$ in diameter, situated near the equator of the body; receptaculum seminis 
large and pedunculated; Laurer's canal present. Vitellaria and Mehlis's gland not yet developed. The uterus passes posteriorly between the testes and then extends anteriorly to the genital pore.

\section{Host.-Delphinus delphis.}

Location.-Intestine.

Distribution.-Europe.

Remarks.-The specimens upon which Poirier (1886) based the description of the foregoing species were still encysted, the cysts being free in the intestine; they were described as spherical and measured $1 \mathrm{~mm}$ in diameter. Looss (1899) referred this species to the genus Astia, which he later (1900) renamed Astiotrema. Jägerskiöld (1908) pointed out that this form was similar to the species $G$. lacteum, which he had previously described from specimens encysted in the brain of Cottus scorpius Bloch. Odhner (1911) was of the opinion that this species was closely related to G. Zacteum, and Bittner and Sprehn (1928) actually placed it in the genus Galactosomum by making the combination of the generic with the specific name.

It seems extremely doubtful whether $G$. erinaceum is a parasite of Delphinus in view of the fact that all other members of the genus are parasites of birds. This was pointed out by Jägerskiöld (1908, p. 317), who states: "Wahrscheinlich ist der Delphin nicht der wirkliche Wirt, sondern die von Poirier gefunden Kapseln sind mit irgendwelchen Fische in den Delphin hineingekommen. Der wirkliche Wirt, falls hier wirklich ein Galatosomum vorleight, ist dagegen wahrscheinlich ein fischfressender Meeresvogel."

\section{Family PARAMPHISTOMATIDAE Fischoeder, 1901}

Family diagnosis.-Medium-sized to large trematodes, with or without ventral pouch. Cuticle without spines. Oral sucker terminal or in some cases retracted into the body; with or without dorsal pocketlike evaginations; acetabulum at posterior end of body. Pharynx absent; intestinal ceca spacious. Excretory vesicle saclike, opening dorsally a short distance from posterioi end of body. Lymph system present. Genital opening ventral, in anterior part of body, with or without genital sucker; cirrus pouch present or absent; testes relatively large, frequently lobed, usually cephalad of ovary. Vitellaria usually well developed. Uterus dorsad of testes. Eggs without filaments. Parasites of mammals, birds, fishes, amphibians, and reptiles.

Type genus.-Paramphistomum Fischoeder, 1901. 
Genus CHIORCHIS Fischoeder, 1901

Generic diagnosis.-Paramphistomatidae: Body ovoid, convex dorsally and flat to slightly concave ventrally; anterior end somewhat attenuated, posterior end rounded; ventral pouch absent. Oral sucker with paired evaginations, usually retracted into an oral canal by the action of strong muscles attached to the oral sucker; acetabulum circular, near posterior end of body. Esophagus relatively short, thick walled; intestinal ceca terminate at middle of acetabular zone. Excretory vesicle large, cephalad of acetabulum. Genital pore at intestinal bifurcation, surrounded by a poorly developed genital sucker; cirrus pouch absent; seminal vesicle much coiled. Testes X shaped, tandem in position. Ovary posttesticular; Mehlis's gland dorsad of ovary; Laurer's canal opens dorsally in front of excretory pore. Vitellaria extracecal, except near tips of ceca, where a few follicles may be intercecal, and extending from a short distance cephalad of intestinal bifurcation to level of anterior margin of acetabulum. Uterus slightly sinuous, in median line dorsad of testes. Eggs large, thin shelled. Parasites of Sirenia.

Type species.-Chiorchis fabaceus (Diesing, 1838) Fischoeder, 1901.

\section{CHIORCHIS FABACEUS (Diesing, 1838) Fischoeder, 1901}

Plate 10, Figures 41-45

Synonym.-Amphistomum fabaceum Diesing, 1838, p. 189; Schizamphistoma manati Sokoloff and Caballero, 1932, pp. 163-167.

Description.-Chiorchis: The body is ovoid in outline, $9 \mathrm{~mm}$ to $11 \mathrm{~mm}$ long by $5 \mathrm{~mm}$ wide, ventral surface flat or slightly concave, dorsal surface strongly convex. The oral opening is slightly subterminal and is followed by an oral canal, the length of which depends upon the degree of retraction of the oral sucker. The oral sucker is about $465 \mu$ to $800 \mu$ in diameter, strongly muscular, and provided with two muscular dorsal pouches. The oral sucker is usually retracted so that its position is about midway between the intestinal bifurcation and the anterior end of the body, the retraction being due to contraction of about 30 muscular bands inserted into the wall of the oral sucker, which radiate posteriorly and attach to the body wall. The acetabulum is ventral, $1.3 \mathrm{~mm}$ to $1.8 \mathrm{~mm}$ in diameter, situated near the posterior end of the body. The esophagus is relatively long and thick walled, its posterior portion being thickened to form a bulblike structure. The intestinal ceca are spacious and thick walled and extend to about the center of the acetabular zone. The excretory pore is situated in the mid-dorsal line slightly cephalad of the level of the ovary; the excretory vesicle is pouch shaped and relatively thick walled. The lymph system consists of two longitudinal vessels which lie dorsally and medially of the 
intestinal ceca and two longitudinal vessels which lie ventrally of the ceca. The dorsal vessels extend the full length of the body and terminate in a number of short, dilated branches. Each vessel gives off about 15 primary branches, which extend lateroventrally and bifurcate to form secondary branches. The secondary branches usually bifurcate to form tertiary branches, each of which terminates in a bulbous swelling near the ventral surface of the body. A number of ventral branches are also given off from the main dorsal canals, but their number and course can not be determined with certainty. The ventral longitudinal canals extend the full length of the intestinal ceca and give off a number of branches, both medially and laterally, which branch again and again and finally terminate in large bulbous swellings; these branches and swellings cover the entire ventral surface of the body beneath the dermomuscular layer. The genital pore is situated immediately caudad of the intestinal bifurcation and is surrounded by a weakly muscular genital sucker. In immature specimens the suckerlike arrangement of the muscular fibers is not so distinct as in more mature specimens. The genital opening communicates with a genital sinus into which projects the prominent genital papilla. The greatly convoluted seminal vesicle lies free in the parenchyma dorsad of the genital pore. The proximal portion of the ejaculatory duct is inclosed in a muscular saclike structure, but distally this sac is very feebly developed or absent. 'The ejaculatory duct unites with the vagina or metraterm to form a hermaphroditic canal, which opens into the genital sinus at the summit of the genital papilla. The testes are $\mathbf{X}$ shaped in mature specimens and almost spherical in immature specimens; they are situated in the median field and are tandem in position. The ovary is almost spherical, about $30 \mu$ in diameter, median in position, and situated about midway between the posterior testis and acetabulum. Mehlis's gland well developed, dorsad of ovary. Laurer's canal is very slender and opens in the mid-dorsal line a short distance cephalad of the excretory pore. The vitellaria are extracecal, except for a few follicles, which are distributed intercecally immediately in front of the acetabulum, and extend anteriorly beyond the intestinal bifurcation. The uterus extends anteriorly in the median line, dorsal to testes, to the level of the cephalic margin of the anterior testis, and then turns ventrally and terminates in a weakly muscular vagina or metraterm. The proximal portion of the uterus may be filled with spermatozoa, and constitutes a receptaculum seminis uterinum. The eggs are oval, about $150 \mu$ long by $90 \mu$ wide, and thin shelled.

Hosts.-Manatus exunguis Natterer (=? Trichechus inunguis Pelzeln), Trichechus latirostris (syn. Manatus latirostris), and T. senegalensis. 
Location.-Large intestine.

Distribution.-North America (Philadelphia Zoological Garden; National Zoological Park, Washington, D. C.; Mexico), South America (Brazil), and Africa (Belgian Congo).

Remarks.-The above description is based largely upon specimens (U.S.N.M. Helm. Coll. No. 24716), collected at Washington, D. C., July 16, 1921, by Dr. E. A. Chapin, these flukes being well preserved and fully mature. Other specimens available for comparison consisted of three lots as follows: U.S.N.M. Helm. Coll. No. 5775, from the Leidy collection, probably a part of the specimens described by Leidy (1891); U.S.N.M. Helm. Coll. No. 18425, collected at Washington, D. C., November 14, 1916, by Dr. L. T. Giltner; and U.S.N.M. Helm. Coll. No. 8416, labeled "F. 1063, Chiorchis fabaceus Dies., stomach and intestine, Manatus senegalensis, Banana, Aug. 1915." The last-named material is from the MacCallum collection and represents a part of the lot of specimens described by Stunkard (1930).

All the specimens examined from these different collections agree in general with the description given for Chiorchis fabaceus by Fischoeder (1903). The majority of the specimens, however, were immature and smaller than the ones upon which the above description is based, and considerable variation was found to exist, especially as regards the shape of the testes. The Leidy specimens were the most immature, and in these the testes varied in shape from spherical to very slightly lobed, none showing the typical $\mathrm{X}$-shaped testes characteristic of the species. They agree, however, in all other respects and must be regarded as the same species as those of the other lots which correspond more closely to the description given by Fischoeder.

\section{Family NOTOCOTYLIDAE Lühe, 1909}

Family diagnosis.-Small to medium-sized monostomes; body usually elongate, tapering anteriorly and rounded posteriorly. Ventral surface usually concave, with or without longitudinal rows of glands or ridges. Oral sucker terminal; pharynx absent; esophagus short; intestinal ceca slender, usually provided with short diverticula. Excretory pore dorsal, near posterior end of body; excretory vesicle with short stem and long branches, which unite near anterior end of body. Genital pore median and situated in anterior part of body, except in Nudacotyle where it is lateral and in posterior part of body; cirrus pouch elongate; testes postequatorial, in same transverse plane, usually extracecal. Ovary between testes; Mehlis's gland complex preovarial; vitellaria lateral, pretesticular; 
uterine coils transverse, regular, pretesticular. Eggs small and provided with a long filament at each pole. Parasites of birds and mammals.

Type genus.-Notocotylus Diesing, 1839.

\section{Subfamily Ogmogasterinae Kossack, 1911}

Subfamily diagnosis.-Notocotylidae: Ventral surface of body provided with longitudinal ridges or rugae. Uterine coils extend anteriorly beyond base of cirrus pouch. Parasites of cetaceans and pinnipeds.

Type genus.-Ogmogaster Jägerskiöld, 1891.

\section{Genus OGMOGASTER Jägerskiöld, 1891}

Generic diagnosis--Ogmogasterinae: Body oval, flattened, and leaflike, margins fluted; ventral surface provided with longitudinal ribs or rugae. Oral sucker terminal; esophagus short; intestinal ceca slender and extending to posterior end of body. Genital aperture median, a short distance caudad of oral sucker; cirrus and vagina open into a short genital sinus. Cirrus pouch long, situated in median line and extending posteriorly to near equator of body; testes deeply lobed, situated in the same transverse plane in the posterior fourth of body. Ovary lobed, median in position and situated at the level of the posterior margin of testes; Mehlis's gland median, preovarial; Laurer's canal present; vitellaria lateral, consisting of isolated follicles and extending from anterior margin of testes to level of the base of the cirrus pouch; uterus greatly convoluted, the coils extending laterally beyond intestinal ceca. Parasites of cetaceans and pinnipeds.

Type species.-Ogmogaster plicatus (Creplin, 1829) Jägerskiöld, 1891.

OGMOGASTER PLICATUS (Creplin, 1829) Jägerskiöld, 1891

\section{Plate 12, Figure 52}

Synonym.-Monostomum plicatum Creplin, 1829, pp. 878-880.

Description.-Ogmogaster: Body oval, $6 \mathrm{~mm}$ to $14 \mathrm{~mm}$ long by an average width of $4 \mathrm{~mm}$, flat and leaflike; the margins of the body have a fluted or pleated appearance, and the ventral surface is provided with 15 to 17 longitudinal rugae. Oral sucker terminal, $500 \mu$ in diameter, according to Leiper and Atkinson (1915); esophagus short; intestinal ceca sinuous and terminating near the posterior end of the body. Excretory pore dorsal, about $700 \mu$ from the posterior end of body, according to Jägerskiöld; excretory vesicle 
$Y$ shaped, situated ventral to ovary and testes. The limbs of the vesicle extend anteriorly and unite at the level of the intestinal bifurcation at which point two branches are given off, one on each side, which extend posteriorly in the lateral fields, then turn and pass anteriorly to the level of the oral sucker, where they again turn and pass backward and terminate near the posterior end of the body. Long branches are given off here and there along the course of the excretory ducts. Genital aperture median, situated a short distance caudad of the oral sucker; the male and female genital pores are situated side by side at the base of a short genital sinus. Cirrus pouch cylindrical, $3 \mathrm{~mm}$ long by $300 \mu$ wide, containing a seminal vesicle, $1.4 \mathrm{~mm}$ long by $200 \mu$ wide, and a long convoluted ejaculatory duct. The ejaculatory duct is lined with a membrane, which is closely beset with small papillalike projections; it may be protruded as a slender cirrus the length of which may equal the length of the body, according to Creplin (1829). Testes deeply lobed, $1 \mathrm{~mm}$ long by $1.1 \mathrm{~mm}$ wide, situated in the same transverse plane in the posterior fourth of the body; vasa efferentia short, uniting to form a relatively wide vas deferens which extends anteriorly in the median line to the base of the cirrus pouch; it then passes to the right of the cirrus pouch where it makes several loops, four to five according to Jägerskiöld, and then passes backward and enters the base of the cirrus pouch. Ovary deeply lobed, $500 \mu$ long by $1 \mathrm{~mm}$ wide, situated between the testes; Mehlis's gland preovarial; Laurer's canal present. Vitellaria lateral, composed of 12 to 16 isolated follicles on each side, lying ventral to ceca, and extending from the anterior margin of the testes to about the level of the base of the cirrus pouch. Uterus slender and greatly convoluted, extending laterally beyond the ceca and from the testes anteriorly to about one-fourth of the body length from the anterior end. Vagina muscular and lined with spines which are about $35 \mu$ long. Eggs elongate oval in shape, $25 \mu$ long, and provided with a long filament at each pole.

Hosts.-Cetacea (Balaenoptera borealis, B. musculus $=$ B. physalus, B. acutorostrata = Balaena rostrata) ; Pinnipedia ${ }^{2}$ (Leptonychotes weddellii, Lobodon carcinophaga).

Location.-Intestine.

Distribution.-Europe (Norway); Antarctic waters (vicinity of Cape Evans).

Remarks.-The above description is taken largely from an exhaustive description of this species given by Jägerskiöld (1891).

${ }^{2}$ Johnston (1931) regards the form from pinnipeds as a species distinct from Ogmogaster plicatus. The new species, for which he proposes the name $O$. antarcticus, differs from 0 . plicatus in "its smaller size, different body proportions, presence of only 13 rugae, more restricted vitelline zone, and relatively smailer cirrus sac." 


\section{Family RHABDIOPOEIDAE Poche, 1926}

Family diagnosis.-Body elongated, rounded at each end, convex dorsally and concave ventrally. Cuticle of ventral surface armed with large, curved, hooklike spines. Posterior end of body provided with large cavity opening dorsally, containing a number of proboscislike, protrusible structures. Excretory pore situated in the floor of the proboscid cavity; excretory vesicle with four anteriorly directed limbs, two lateral and two median; the lateral pair of branches unite near the intestinal bifurcation and possess short lateral diverticula; the median branches are intercecal and terminate blindly near intestinal bifurcation. Oral sucker subterminal; esophagus slender; intestinal ceca pass between testes and unite at posterior end of body. Genital aperture situated at side of oral sucker; cirrus pouch long and slender, containing a portion of seminal vesicle. Testes extracecal, situated in the same transverse plane near the posterior end of body. Ovary between testes; seminal receptacle and Laurer's canal absent. Vitellaria extracecal and posttesticular. Uterus long and slender, with numerous transverse loops extending beyond lateral limits of the intestinal ceca; vagina as long as cirrus pouch. Eggs small, provided with a long filament at each pole. Parasitic in Sirenia.

Type genus.-Rhabdiopoeus S. J. Johnston, 1913.

Genus RHABDIOPOEUS S. J. Johnston, 1913

Generic diagnosis.-Rhabdiopoeidae: Characters of the family.

Type species.-Rhabdiopoeus taylori S. J. Johnston, 1913.

RHABDIOPOEUS TAYLORI S. J. Johnston, 1913

\section{Plate 12, Figure 51}

Description.-Rhabdiopoeus: Body elongated and lancelike, $22 \mathrm{~mm}$ long by $5 \mathrm{~mm}$ wide; thinner anteriorly than posteriorly; dorsal surface convex; ventral surface flat or slightly concave anteriorly and more deeply concave posteriorly. The ventral surface is covered with large, recurved, hooklike spines, $107 \mu$ long by $64 \mu$ wide at their bases; they are set in a thick cuticula. Oral sucker almost circular, $733 \mu$ in diameter, subterminal and directed ventrally; esophagus moderately long; intestinal ceca slender, united at posterior end of body; small lateral ceca are present along the posttesticular portions, but absent elsewhere along their course. A large cavity, opening dorsally, is present near the posterior end of the body; this cavity communicates with nine tunnel-like tubular spaces, three of which are anterior and the remaining six are arranged in 
two lateral groups of three, each containing a protrusible fingerlike proboscis. The excretory pore is situated in the floor of the proboscid chamber; excretory vesicle large and branched, each of the branches becoming narrowed into 1 of the 4 chief trunk vessels, 2 of the vessels being median and 2 lateral. The lateral vessels extend anteriorly, lateral of testes, and unite immediately anterior and ventral of the intestinal bifurcation; they are provided with short lateral branches along their course from the level of the anterior margin of the testes to the level of the intestinal bifurcation. The two median vessels pass between the testes and extend anteriorly in the intercecal field to near the intestinal bifurcation where they terminate blindly. Genital aperture near right margin of oral sucker. Cirrus pouch long and slender, its posterior end lying in the median line about one-fourth of the body length from the anterior end; it contains a small portion of the seminal vesicle, an ejaculatory duct surrounded by prostate cells, and a muscular cirrus. Testes deeply lobed, about $2 \mathrm{~mm}$ long by $940 \mu$ wide, situated in the same transverse plane near the junction of the third and last body fourths; they are so situated that their long axes are oblique to the long axis of the body, their bases being separated by the intestinal ceca. The vas deferens is expanded to form a relatively wide seminal vesicle which extends anteriorly in a more or less tortuous course from the level of the anterior margin of the testes to the cirrus pouch. Ovary oval, $890 \mu$ long by $570 \mu$ wide; Mehlis's gland $820 \mu$ long by $490 \mu$ wide, situated to the right of ovary; both ovary and Mehlis's gland lie in the angle formed by the testes. There is no seminal receptacle or Laurer's canal. Vitellaria extracecal and posttesticular in position, and consisting of grapelike groups of oval follicles, each lateral mass being composed of about 50 groups. Uterus long and slender, composed of numerous, closely packed transverse loops which extend laterally beyond the limits of the ceca as far as the lateral branches of the excretory system. Eggs $26 \mu$ long by $15 \mu$ wide, thin shelled, and with a long filament at each pole.

Host.-Halicore dugong.

Location.-Intestine.

Distribution.-Australia (coast of Queensland).

Family OPISTHOTREMATIDAE Poche, 1926

Family diagnosis.-Body spoon shaped; ventral surface spiny. Esophagus moderately long, slender; intestinal ceca without diverticula. Excretory pore dorsal; excretory vesicle short and with lateral branches. Genital openings median and situated almost at extreme posterior end of body. Cirrus pouch long and slender, median, containing a strongly convoluted seminal vesicle and a protrusible 
cirrus; testes intercecal or extracecal, situated in the same transverse plane in the posterior part of body. Ovary either dextral or sinistral in position, pretesticular; Mehlis's gland postovarial; seminal receptacle present; Laurer's canal present or absent; vitellaria weakly developed, intercecal, pretesticular; uterus long and slender, occupying the greater portion of the central part of body, usually confined to the intercecal field. Eggs with long polar filaments. Parasites of respiratory passages of Sirenia.

Type genus.-Opisthotrema Fischer, 1883.

KEY TO THE GENERA OF OPISTHOTREMATIDAE

1. Testes extracecal Opisthotrema (p. 49).

Testes intercecal Pulmonicola (p. 55).

Genus OPISTHOTREMA Fischer, 1883

Synonym.-Cochleotrema Travassos and Vogelsang, 1931.

Generic diagnosis.-Opisthotrematidae: Body oval to piriform in shape, flattened dorsoventrally, dorsum strongly arched and venter strongly concave; margin of body may or may not be provided with a muscular rim. Cuticle of ventral surface spiny. Oral sucker ventral, situated a short distance from the anterior margin of body; pharynx absent; esophagus slender and of medium length; intestinal ceca more or less sinuous and extending into the posterior fourth of body. Excretory pore dorsal and somewhat removed from the posterior margin; excretory vesicle tubular and provided with lateral branches. Genital pores at posterior end of body; cirrus pouch long and slender, containing a slender, convoluted seminal vesicle and a long, slender, protrusible cirrus; testes lobed, situated extracecally in the same transverse plane in the posterior part of body. Ovary lobed, to the right or left of the median line anterior to and separated from the testis on the corresponding side by the intestinal cecum, which passes between them; Mehlis's gland well developed; seminal receptacle present; Laurer's canal present or absent; vitellaria intercecal and consist of a grapelike mass of follicles on each side of median line, or of a mass of irregular follicles in the median field. Uterus long, slender, and convoluted, occupying the greater part of the central portion of the body; vagina long, slender, slightly sinuous, and provided with relatively strong muscular walls. Eggs oval and provided with a slender filament at each pole. Parasites of the respiratory tract and eustachian tubes of Sirenia.

Type species.-Opisthotrema cochleare Fischer, 1883 (=Monostomum dujonis Leuckart, 1874).

Remarks.-The foregoing diagnosis is based on the characters common for the two species which are described later. The writer 
recognizes the genus Pulmonicola, which was proposed by Poche (1926), as distinct from the genus Opisthotrema on the ground that the intercecal position of the testes in Pulmonicola pulmonalis is too great a difference to be regarded as being a character of only specific value.

KEY TO THE SPECIES OF THE GENUS OPISTHOTREMA

1. Body piriform in outline; distinct muscular rim absent; intestinal ceca relatively wide, their blind ends diverging-- dujonis (p.50).

Body oval in outline; distinct muscular rim present; intestinal ceca slender, their blind ends converging --__-_-_--- cochleotrema (p.52).

OPISTHOTREMA DUJONIS (Leuckart, 1874), new combination

Plate 11, Figure 46

Synonyms.-Monostomum dujonis Leuckart, 1874, p. 419; Opisthotrema cochleare Fischer, 1883, pp. 1-42.

Description.-Opisthotrema: Body piriform in outline, 9 to $11 \mathrm{~mm}$ long by $5 \mathrm{~mm}$ wide; the dorsal surface is strongly convex and the ventral surface concave, which gives the body the appearance of the bowl of a spoon. Cuticle spiny on ventral surface, according to Fischer, and also on anterior part of dorsal surface, according to Johnston (1913). Oral sucker ventral, $600 \mu$ long by $850 \mu$ wide, situated about $460 \mu$ from the anterior end of body; esophagus slender, about $1 \mathrm{~mm}$ long by $80 \mu$ wide; intestinal ceca relatively wide, slightly sinuous and extending to near the posterior end of the body, their blind ends somewhat distended and diverging. The excretory system consists of two canals, one on each side, united by a commissure a short distance caudad of the intestinal bifurcation and again by a similar commissure about midway between the intestinal bifurcation and the posterior margin of the oral sucker. Each of the canals is provided with lateral branches, which extend to the margin of the body. Excretory vesicle (?); excretory pore (?). According to Fischer, the canals terminate near the ends of the ceca and probably open separately. The cirrus pouch is cylindrical, $2 \mathrm{~mm}$ long by $245 \mu$ wide, situated in the median line in the posterior part of the body, containing a greatly convoluted seminal vesicle and a slender protrusible cirrus; genital pore ventral, near posterior margin. Testes lobed, $250 \mu$ to $540 \mu$ in diameter, situated in the same transverse plane and extracecal in position. Ovary small, lobate, situated to the left of the median line and a short distance cephalad of the level of the testes; Mehlis's gland small, caudad of ovary; Laurer's canal present, the proximal part of the canal being expanded 
to form a seminal receptacle measuring $170 \mu$ long by $57 \mu$ wide. Vitellaria weakly developed, consisting of a few follicles situated along the vitelline duct at each side of the intercecal field. Uterus slender and occupying the intercecal space in the equatorial third of the body; during its course the uterus describes a number of loops which form a treelike pattern. The distal portion of the uterus is expanded to form an egg reservoir and continues as a slender vagina, which opens beside the male genital aperture. Eggs oval in outline, $29 \mu$ long by $9 \mu$ wide, provided with a long, slender filament at each pole.

\section{Host.-Haticore dugong.}

Location.-Eustachian tubes and esophagus.

Distribution.-Philippine Islands; Australia.

Remarks.-This species was named Monostomum dujonis by Leuckart (1874) in a review of Zeller's (1874) paper "Uber Leucochloridium paradoxum Carus and die weitere Entwickelung seiner Distomenbrut." In this review, Leuckart, in commenting on the genital system of $L$. paradoxum, stated: "Und seine Generationsorgane in allen ihren Theilen vollstandig und deutlich erkennen lässt. Die Ausmündung derselben liegt, wie sonst nur bei wenigen Distomeen-Ref. kennt auch ein Monostomum, das sich ganz ähnlich verhält, $M$. dujonis, das Semper in den Eustachischen Röhren des Dujung der Philippinen sammelte und dem Ref. freundlichst zur Untersuchung uberlassen hat-an Hinterende des Körpers, dicht neben der des excretorischen Apparates." Fischer's (1883) description of Opisthotrema cochleare is based unquestionably upon a study of the specimens which Leuckart referred to, since he stated in the introduction of his paper: "Besagte Form wurde von Herrn Prof. Semper in Würtzburg auf seiner Expedition nach den Philippinen gesammelt. Sie entstammt der Paukenhöhle von Halicore Dugong."

The name given to this worm by Leuckart can not be regarded as a nomen nudum because an important morphological character, the position of the genital pore, is pointed out and in addition are given the host and habitat of the species. It is, therefore, the opinion of the writer that the correct name for this species is Opisthotrema dujonis (Leuckart), since the rules of zoological nomenclature state: "Art. 25.-The valid name of a genus or species can be only that name under which it was first designated on the condition: a) That this name was published and accompanied by an indication, or a definition, or a description;" etc. The description given by Leuckart is more in the form of a comparison than an actual description, but it appears sufficient to fix the specific name, since the rules do not state how much description should be given. 
OPISTHOTREMA COCHLEOTREMA (Travassos and Vogelsang, $1931^{3}$ ) new combination

Plate 11, Figure 47-49

Synonyms.-Amphistomum fabaceum Diesing of Leidy, 1891, pp. 413-414, in part; Opisthotrema cochleare Fischer of Stiles and Hassall, 1894, p. 253; Cochleotrema cochleotrema Travassos and Vogelsang, 1931, pp. 143-146.

Description.-Opisthotrema: The body is oval in outline, $8.5 \mathrm{~mm}$ long by $6.5 \mathrm{~mm}$ wide, strongly concave ventrally and convex dorsally; the margin of the body is surrounded by a more or less delicate muscular rim, which is about $250 \mu$ wide. The strongly convexo-concave condition of the body suggests that the entire worm attaches itself to the mucous membrane in the manner of a vacuum cup, the muscular rim serving as a sort of seal. The cuticle of the ventral surface is covered with scalelike spines, $7 \mu$ long by $4 \mu$ wide, arranged in irregular alternating rows. The excretory pore is situated dorsally, about $930 \mu$ from the posterior end of the body, the aperture being surrounded by a muscular sphincter. The excretory vesicle is tubular, about $1 \mathrm{~mm}$ long, and is provided with two principal branches on each side; the first branch occurs at the level of the blind ends of the ceca and the other at the anterior end of the vesicle; two smaller branches are given off on each side a short distance caudad of the anterior branches. The remainder of the excretory system could not be worked out in detail, but judged from sections the course of the principal branches is probably similar to that described by Fischer for $O$. cochleare. The oral sucker is transversely oval, $1 \mathrm{~mm}$ long by $1.3 \mathrm{~mm}$ wide, strongly muscular, and situated ventrally about $465 \mu$ from the anterior margin of the body; it is deeply imbedded in the parenchyma and projects only slightly beyond the ventral surface. The esophagus is slender and about $465 \mu$ long; the intestinal ceca are slender and serpentine, $155 \mu$ wide, the blind ends converging toward the median line. Cirrus pouch slender, about $3 \mathrm{~mm}$ long by $155 \mu$ wide at the level of the testes; the walls are moderately thick

\footnotetext{
${ }^{3}$ This species was described by the writer as new in the present paper, but while the manuscript was awaiting publication a description appeared by Travassos and Vogelsang (1931) of a species from Trichechus manatus which appears to be the same form. The description given herein is from the writer's specimens. Some slight differences exist between this and the description given by Travassos and Vogelsang, but these differences appear to be those of interpretation. Travassos and Vogelsang note that in their specimens the ventral surface is covered with small papillae similar to those occurring on the ventral surface of Gastrodiscus, and that Laurer's canal is present. In the specimens at the writer's disposal the ventral surface is covered with small triangular, scalelike spines (pl. 11, fig. 49) and no Laurer's canal is present. The absence of Laurer's canal is shown in pl. 11, fig. 48 , which is a reconstruction from serial sections.

The writer does not agree with Travassos and Vogelsang as to the necessity of creating a new genus for this species, since the differences between this species and the type of the genus are too slight to warrant such action.
} 
and muscular, both circular and longitudinal fibers being present. The seminal vesicle is slender and greatly convoluted, and occupies the basal third of the cirrus pouch. A definite pars prostatica appears to be absent although some prostate cells are present along the distal, less convoluted portion of the seminal vesicle. The cirrus is slender, about $2 \mathrm{~mm}$ long, unarmed and protrusible. The genital aperture is ventral and situated at the posterior end of the body at the junction of the muscular rim with the body proper. The testes are deeply lobed, about $850 \mu$ by $620 \mu$, extracecal and opposite each other in the posterior third of the body. The ovary is irregular in outline but not deeply lobed, about $435 \mu$ in diameter, situated to the right of the median line, intercecal and pretesticular. Mehlis's gland is composed of large piriform cells and is situated median and slightly dorsal to the ovary. The seminal receptacle is muscular, more or less oblong, about $697 \mu$ long by $155 \mu$ wide, and situated dorsal to Mehlis's gland. There is no Laurer's canal. The vitellaria consist of relatively few, large, irregularly shaped follicles situated in the intercecal space between the equator of the body and the testes; the follicles are not divided into two separate groups as in $O$. dujonis, but form a single, more or less grapelike mass. The uterus is greatly convoluted, forming a wreathlike mass of loops which occupies the greater part of the central portion of the body; the loops extend slightly beyond the ceca laterally, but do not extend anteriorly beyond the intestinal bifurcation. The terminal portion of the uterus is continued as a muscular walled, slightly sinuous vagina or metraterm, which runs dorsal to the cirrus pouch and opens beside the male genital aperture. The eggs are oval in shape, $18 \mu$ long by $11 \mu$ wide, light straw colored, and provided with a long, slender filament at each pole.

Hosts.-Trichechus manatus and T. Tatirostris (= Manatus Tatirostris.)

Location.-Nasal passages and stomach.

Distribution.-North America (United States-Philadelphia, Pa.), and Tropical America.

Specimens.-U.S.N.M. Helm. Coll. No. 1732.

Remarks.-In a note presented at a meeting of the Philadelphia Academy of Natural Sciences, Leidy (1891) reported the occurrence of Amphistomum fabaceum Diesing in a sea cow, Manatus latirostris, which died in the zoological garden. These specimens had been collected from the large intestine and submitted by Dr. H. C. Chapman. In the same note he said: "Numerous specimens, many of larger size, up to $11 \mathrm{~mm}$ long by $9 \mathrm{~mm}$ broad, were obtained from the nasal passages of another sea cow, and were presented to the Academy by Jacob Geismar." 
Stiles and Hassall (1894) examined the trematodes of the Leidy collection and redetermined the specimens reported from the nasal passages as Opisthotrema cochleare Fischer. A part of the material, two specimens, was retained in the United States National Museum collection, and it is upon these that the foregoing description of Opisthotrema cochleotrema is based.

These specimens are sexually mature, but somewhat smaller than those reported by Leidy. One of them was stained and mounted whole; the other was stained and sectioned. The description given above is a composite one, the details being obtained from the sectioned specimen.

Opisthotrema cochleotrema differs in a number of respects from 0 . dujonis (Leuckart) $(=0$. cochleare Fischer), so that there appears to be no doubt that they are distinct species. O. cochleotrema is provided with a muscular rim similar to that described for Pulmonicola pulmonalis (von Linstow); the intestinal ceca are slender and uniform in diameter, serpentine, and their blind ends converge; Laurer's canal is absent; and the terminal part of the uterus is not expanded to form an egg reservoir. In $O$. dujonis the body is not provided with a muscular rim; the intestinal ceca are not of uniform width, only slightly sinuous, and their blind ends diverge; Laurer's canal is present; and the distal part of the uterus is expanded to form an egg reservoir. Other differences may be easily seen by comparing the descriptions and figures of the two species.

Fischer's (1883) figure of Opisthotrema cochleare $(=0$. dujonis) leaves the impression that the principal branches of the excretory system open separately and in this connection he states "indem wahrscheinlich nicht eine, sondern zwei Mündungsstellen vorhanden dürften, die der ventralen Seite angehören und jederseits unterhalb der Darmschenkel liegen." Poche (1926) doubts the presence of two excretory pores in this species, but Fuhrmann (1929) believes that two openings should be present and has indicated in the figure of $O$. cochleare ("nach Fischer") just where these openings should be located. The study of serial sections of $O$. cochleotrema has shown that the position of the excretory pore in this species is essentially the same as that in members of the family Notocotylidae ${ }^{4}$ and Pronocephalidae. In view of this fact it appears reasonable to assume that the position of the excretory pore in $O$. dujonis will be

\footnotetext{
${ }^{4}$ In Poche's (1926) classification of the trematodes, the monostomes belonging to the families Notocotylidae, Pronocephalidae, Opisthotrematidae, and Rhabdiopoeidae are placed in the super-superfamily Notocotylida. Since groups of the rank of super-superfamily have not been recognized by helminthologists and are unnecessary at present, the writer proposes at this time the new superfamily Notocotyloidea, to replace the super-superfamily Notocotylida Poche.
} 
found to be the same as that in $O$. cochleotrema, as it would be unusual to find such marked differences in two species so closely related.

Genus PULMONICOLA Poche, 1926

Generic diagnosis.-Opisthotrematidae: Entire margin of body, except space occupied by oral sucker, provided with a muscular rim. Cuticle without spines. Oral sucker ventral, near anterior margin of body; intestinal ceca straight, uniform in diameter. Excretory system (?), probably similar to that in Opisthotrema. Testes entire, intercecal, situated near ends of ceca. Ovary median. Other characters as in Opisthotrema.

Type species.-Pulmonicola pulmonalis (von Linstow, 1904) Poche, 1926.

PUlmonicola PUlmonalis (von Linstow, 1904) Poche, 1926

Plate 11, Figure 50

Synonyms.-Opisthotrema pulmonale von Linstow, 1904, pp. 678-680.

Description.-Pulmonicola: Body oval in outline, $5.13 \mathrm{~mm}$ long by $3.95 \mathrm{~mm}$ wide; margin of body, except for the portion occupied by the oral sucker, modified to form a muscular rim. Oral sucker situated on ventral surface, $330 \mu$ from the anterior margin; esophagus very slender, $180 \mu$ long by $28 \mu$ wide; intestinal ceca uniform in diameter and extending into the posterior fourth of body. Cirrus pouch slender, spirally coiled distally, and containing a greatly convoluted seminal vesicle. Testes oval, entire, $390 \mu$ long by $280 \mu$ wide, situated intercecally in the same transverse plane. Ovary small, median in position, situated a short distance caudad of the equator of body; Mehlis's gland smaller than ovary and situated immediately caudad of it; receptaculum seminis present; Laurer's canal present. Vitellaria in intercecal field and consisting of a few isolated follicles situated between the ovary and testes. Uterus slender, intercecal, occupying the equatorial third of body in immature specimens, but in mature specimens more convoluted and occupying the second and third fourths of the body; vagina dorsal to cirrus pouch; genital pore at posterior end of body. Eggs $16 \mu$ long by $9 \mu$ wide, yellow in color, and provided with a long filament at each pole.

Hosts.-Halicore australe, H. dugong.

Location.-Lung.

Distribution.-Australia (Torres Straits). 


\section{SPECIES OF UNCERTAIN POSITION}

DISTOMA ANDERSONI Cobbold, 1876

Plate 12, Figure 53

Description.- " Body oblong, smooth externally, uniform in thickness, six times as long as broad; head with lateral projections; ventral sucker large and prominent; neck much constricted; tail evenly rounded off, blunt. Length $1 / 8^{\prime \prime}$, breadth about $1 / 50^{\prime \prime}$. The testes are globular and placed high up in the middle line of the body. The small lobed gland immediately above them is probably the ovary. The clear narrow line extending from the border of the lower testis to the end of the tail seems to mark the limit of the vitellogene organs on either side below. These glands in all likelihood extend upwards to the neck, being apparently very largely developed in this species."

Host.-Platanista gangetica.

Location.-Small intestine.

Distribution.-Asia (India).

Remarks.-The foregoing description, copied from Cobbold (1876), was based upon a drawing sent to him by Dr. John Anderson, superintendent of the Indian Museum, Calcutta. Odhner (1905) believed that this worm was probably related to Brachycladium (=Campula), as he stated: "Endlich finde ich sehr wahrscheinlich, dass das sehr ungenügend bekannte Dist. andersoni Cobb. aus Platanista gangetica sich bei genauerer Untersuchung als eine Brachycladium-Art entpuppen wird." It is probably unwise to venture an opinion as to the systematic position of this species, but certain features as shown in the drawing, assuming that the sketch was not made from a mutilated specimen, suggest that this form might be an echinostome. The anterior end is not unlike the cephalic collar of the echinostomes; the small oral sucker and the large acetabulum, as well as the relative size and position of the ovary and testes, suggest such affinities. On the other hand, what is figured as the oral sucker may be only the oral aperture, and the structure which resembles a cephalic collar may in reality be the oral sucker which has been torn loose from the body.

\section{DISTOMUM PHILOCHOLUM Creplin, 1845}

Description.-None.

Host.-Delphinus delphis.

Location.-Liver.

Distribution.-Europe.

Remarks.-Creplin (1845) gives only the name and habitat of this species, and for this reason it must be regarded as a nomen nudum. 
Synonyms.-Monostomum delphini Diesing, 1850, p. 390; Monostomum blainvillei Cobbold, 1860, p. 39; Monostomulum delphini (Diesing, 1850) Brandes, 1892, p. 510.

Description.-The following is the only existing description of this worm and is quoted verbatim from de Blainville (1825):

En enlevant la graisse de cet animal [a whale], on a trouvé, enfermé dans son épaisseur, et contenu dans une sorte de kyste à parois lisses en dedans, mais non distinctes en dehors, un ver assez singulier, que M. de Blainville crut d'abord pouvoir rapporter au genre Monostome, mais qui en diffère sensiblement, comme on va le voir; il était replié dans son kyste, et vivant, quoique le dauphin fat mort depuis cinq ou six jours. Mis dans de l'eau froide, il se contractait dans tous les sens, de maniere à présenter une form extrèmement variable, quelquefois globuleuse, d'autres fois ovale-alongée, etranglée au milieu ou nouée, avec une sorte de queue en arrière ou de tube en avant; son extrémité anterieure souvent atténuée et cylindrique, présentait un orifice évident de form circulaire. Il en existait aussi un autre a l'extrémité postérieure, mais beaucoup plus petit, et au milieu d'une sorte d'auréole plus grise; enfin, sur un individu, M. de Blainville a vu, à peu près à la moité de la longueur et en dessous, une petite masse blanche, ovale, saillante en dehors, un peu comme dans les fascioles, ou distomes. Ce ver, d'une couleur blanche mate, était formé d'une sorte d'enveloppe épaisse de cette couleur, et d'une autre intestinale comme gélatineuse.

\section{Host.-Delphinus dalei (probably=Mesoplodon bidens).}

Location.-Encysted in fat.

Distribution.-Europe (Havre, France).

Remarks.-Diesing (1850) regarded this species as an immature monostome, as did Cobbold (1860) and Brandes (1892). The description and habitat, however, do not sustain this assumption. So far as known, the true monostomes do not encyst as larvae in the body of vertebrates, but encyst in water and become attached to herbage or other objects, or remain floating. Certain features of this form as given in de Blainville's description, especially the small, oval projection on the ventral surface situated about the middle of the body (à peu près à la moité de la longeur et en dessous, une petite masse blanche, ovale, saillante en dehors), suggest that this worm is the metacercaria of a species of Alaria or that of a related genus, the oval body corresponding to the holdfast organ of these forms. This species, therefore, has been transferred to the collective distome genus Agamodistomum. 


\section{LIST OF TREMATODES ARRANGED ACCORDING TO HOSTS ${ }^{5}$}

\section{Order CETACEA}

Suborder MYSTICETI

Family BALAENIDAE

Balaena mysticetus:

Lecithodesmus goliath (van Beneden).

\section{Family BALAENOPTERIDAE}

Balaenoptera acutorostrata (syn. $B$. rostrata):

Fasciola hepatica Linnaeus.

Lecithodesmus goliath (van Beneden).

Ogmogaster plicatus (Creplin).

Balaenoptera borealis:

Lecithodesmus goliath (van Beneden).

Ogmogaster plicatus (Creplin).

Balaenoptera physalus (syn. B. musculus Companyo):

Ogmogaster plicatus (Creplin).

\section{Suborder ODONTOCETI}

Family DELPHINIDAE

Delphinus delphis:

Campula delphini (Poirier).

Campula palliata (Looss).

Campula rochebruni (Poirier).

Galactosomum erinaceum (Poirier).

Distomum philocholum Creplin.

Tursiops truncatus (syn. Delphinus tursio) :

Synthesium tursionis (Marchi).

Orcinus orca (syn. Orca gladiator):

Fasciola hepatica Linnaeus.

Orcaella brevirostris:

?Amphimerus lancea (Diesing).

Phocaena phocoena (syn. P. communis ) :

Campula oblonga Cobbold.

opisthorchis tenuicollis (Rudolphi).

Pholeter gastrophilus (Kossack).
Sotalia tucuxi (syn. ? Delphinus tacuschi).

Amphimerus lancea (Diesing).

Delphinapterus leucas:

Hadwenius seymouri, new species.

Family PLATANISTIDAE

Platanista gangetica:

Cyclorchis campula (Cobbold).

Distoma andersoni Cobbold.

\section{Family ZIPHIIDAE}

Mesoplodon bidens (syn. ? Delphinus dalei) :

Agamodistomum delphini (Diesing).

\section{Order SIRENIA}

Family TRICHECHIDAE

Trichechus inunguis (syn. ? Manatus exunguis Natterer):

Chiorchis fabaceus (Diesing).

Trichechus latirostris:

Chiorchis fabaceus (Diesing).

Opisthotrema cochleotrema (Travassos and Vogelsang).

Trichechus manatus:

Opisthotrema cochleotrema (Travassos and Vogelsang).

Trichechus senegalensis:

Chiorchis fabaceus (Diesing).

\section{Family HALICORIDAE}

Halicore dugong (syn. H. cetacea):

opisthotrema dujonis (Leuckart).

Rhabdiopoeus taylori S. J. Johnston.

Pulmonicola pulmonale (von Linstow).

Halicore australe:

Pulmonicola pulmonale (von Linstow).

5 The writer is indebted to Dr. Remington Kellogg, assistant curator of the division of mammals of the United States National Museum, for suggesting the probable identifications of the hosts. 


\section{Order PINNIPEDIA}

Fan.ily OTARIIDAE

\section{Zalophus californianus:}

Apophallus zalophi, new species. Zalophotrema hepaticum Stunkard and Alvey.

Stephanoprora denticulata (Rudolphi).

\section{Family PHOCIDAE}

Phoca groenlandica:

Pseudamphistomum $t r u n c a t u m$ (Rudolphi).

Phoca hispida (syn. Halichoerus foetidus) :

Orthosplanchnus arcticus Odhner. Phocitrema fusiforme Goto and Ozaki.

Pseudamphistomum $t r u n c a t u m$ (Rudolphi).

Phoca vitulina:

Apophallus donicus (Skrjabin and Lindtrop ).

Cryptocotyle lingua (Creplin).

Echinostoma acanthoides (Rudolphi ).

Pseudamphistomum $t r u n c a t u m$ (Rudolphi).
Erignathus barbatus (syn. Phoca barbata) :

Opisthorchis te nuicollis (Rudolphi).

Orthosplanchnus arcticus odhner. Orthosplanchmus fraterculus Odhner.

Halichoerus grypus:

Metorchis albidus (Braun).

opisthorchis tenuicollis (Rudolphi).

Pseudamphistomum truncat $u m$ (Rudolphi) .

Leptonychotes weddellii:

Ogmogaster plicatus (Creplin).

Lobodon carcinophaga:

Ogmogaster plicatus (Creplin).

\section{Family ODOBENIDAE}

Mirounga angustirostris (syn. Macrorhinus angustirostris) :

Cryptocotyle lingua (Creplin).

Odobenus rosmarus:

Odhneriella rossica Skrjabin.

Orthosplanchnus frateroulus Odhner. 
AFrica, CANDido M.

\section{BIBLIOGRAPHY}

1929. On two German Heterophyidae with notes on the variability of certain structures. Centralb. für Bakt., Parasit. und Infekt., Abt. 1, Orig., vol. 114, nos. 1-2, pp. 81-86, figs. 1-4; German summary, p. 86.

Barker, Franklin D.

1911. The trematode genus Opisthorchis R. Blanchard, 1895. Studies Zool. Lab. Univ. Nebraska, no. 103, pp. (513)-561, 3 tables, pls. 17-20. (Advance separate from Arch. de Parasitologie, vol. 14, no. 4, pp. 513-561, pls. 17-20.) Paris.

Beneden, P. J. van.

1858. Note sur une nouvelle espèce de distome, le géant de sa famille. habitant le foie d'une baleine, nommée Distoma goliath v. Ben. Bull. Acad. Roy. Sci., Lettres, et Beaux-arts Belgique, ser. 2, vol. 5, no. 7, pp. 95-97, 1 pl., figs. 1-5. Brussels.

Bittner, H., ANd Sprehn, C.

1928. Trematodes. Saugwürmer. Biologie der Tiere Deutschlands (Schulze), vol. 27, pt. 5, pp. 1-133, figs. 1-56. Berlin.

Blainville, Marie Henri Ducrotay de.

1825. Note sur un cétacé échoué au Hâvre, et sur un ver trouvé dans sa graisse. Nouveau Bull. Sci. Soc. Philom. Paris, Sept., pp. 139-141.

Blanchard, Raphaet.

1895. Animaux parasites (preliminary notice). Bull. Soc. Zool. France, vol. 20 , nos. $8-9$, p. 217.

Brandes, G.

1892. Revision der Monostomiden. Centralb. für Bakt., Parasit. und Infekt., vol. 12, no. 15, pp. 504-511.

Braun, Max.

1892. Verzeichniss von Eingeweidewürmern aus Mecklenburg. Arch. Ver. Freunde Naturg. Mecklenburg, vol. 45, no. 2, pp. 97-117.

1893. Die Leberdistomen der Hauskatze (Felis catus domesticus und verwandte Arten). Centralb. für Bakt., Parasit. und Infekt., vol. 14, no. 12 , pp. 381-392; no. 13 , pp. $422-428$, figs. $1-4$.

1900. Über Campula oblonga Cobb. Centralb. für Bakt., Parasit. und Infekt., Abt. 1, vol. 28, nos. 8-9, pp. 249-254, figs. 1-3.

1901a. Zur Kenntniss der Trematoden der Säugethiere. Zool. Jahrb. (Abt. Syst.), vol. 14, no. 4, pp. 311-348, pls. 19-20, figs. 1-17.

1901b. Zur Revision der Trematoden der Vögel. I. Contralb. für Bakt, Parasit. und Infekt., Abt. 1, vol. 29, no. 13, pp. 560-568.

1901c. Zur Revision der Trematoden der Vögel. II. Centralb. für Bakt., Parasit. und Infekt., Abt. 1, vol. 29, no. 23, pp. 895-897.

1902a. Fascioliden der Vögel. Zool. Jahrb. (Abt. Syst.), vol. 16, no. 1, pp. 1-162, pls. 1-8, figs. $1-99$.

1902b. Über Distoma goliath P. J. Van Ben., 1858. Centralb. für Bakt., Parasit. und Infekt., Abt. 1, Orig., vol. 32, no. 11, pp. 800-803, 1 pl., figs. 1-2.

Buttel-Reepen, H.

1902. Zur Kentniss der Gruppe des Distomum clavatum, insbesondere des Dist. ampullaceum und des Dist. siemersi. Zool. Jahrb. (Abt. Syst.), vol. 17, no. 2, pp. 165-236, pls. 6-10, figs. 1-54. 


\section{Ciurea, J.}

1924. Heterophyides de la faune parasitaire de Roumanie. Parasitology, vol. 16 , no. 1, pp. 1-21, pls. 1-5, figs. 1-19.

Cobbold, Thomas Spencer.

1858. Observations on Entozoa, with notices of several new species, including an account of two experiments in regard to the breeding of Taenia serrata and T. cucumerina. Trans. Linn. Soc. London, vol. 22 , pt. 3 , pp. $155-172$, pls. $31-33$, figs. $1-85$.

1860. Synopsis of the Distomidae. Journ. Proc. Linn. Soc. London, Zool., no. 17 , vol. 5, pp. 1-56.

1876. Trematode parasites from the dolphins of the Ganges, Platanista gangetica and Orcella brevirostris. Journ. Linn. Soc. London, Zool., no. 65 , vol. 13 , pp. 35-46, 1 fig., pl. 10, figs. 1-3.

COOPER, A. R.

1921. Trematodes and cestodes of the Canadian Arctic Expedition 1913-18. Rep. Canadian Arctic Exped., vol. 9, part GH, pp. (3)-27, pls. 1-2, figs. 1-15. Ottawa.

Creplin, Fridrich Christian Henrich.

1825. Observations de entozois, 86 pp., 1 pl., 17 figs. Gryphiswaldiae.

1829. Filariae et Monostomi speciem novam in Balaena rostrata repertam. Nova Acta Phys.-Med. Acad. Nat. Curios., vol. 14, no. 2, pp. 871-882, pl. 52, igs. 1-11. Bonn.

1845. Nachträge zu Gurlt's Verzeichniss der Thiere, bei welchen Entozoen gefunden worden sind. Arch. für Naturg., Jahr. 11, vol. 1, pp. $325-336$.

Diesing, Karl Moritz.

1838. [Abbildungen neuer Gattungen brasilianischer Binnenwürmer (Entozöen) ] (Secretary's abstract). Ber. Versamml. deutsch. Naturf. und Aerzte in Prag, Sept., 1837, p. 189.

1839. Neue Gattungen von Binnenwürmern nebst einem Nachtrage zur Monographie der Amphistomen. Ann. Wien Mus. Naturg., vol. 2, no. 2, pp. 219-242, pls. 14-20.

1850. Systema helminthum, vol. 1, 679, pp. Vindobonae.

1855. Neunzehn Arten von Trematoden. Denkschr. Kais. Akad. Wiss. math.-naturw., vol. 10 , pt. 1 , pp. 59-70, pls. 1-3. Wien.

1858. Revision der Myzhelminthen. Abtheilung: Trematoden. Sitz. Akad. Wiss. Wien, Math.-naturw. Cl., vol. 32, no. 23, pp. 207-390, pls. $1-2$.

Dietz, Eugene.

1909a. Die Echinostomiden der Vögel. Zool. Anz., vol. 34, no. 6, pp. 183-192.

1909b. Idem. Diss. 37 pp., 8 figs. Königsburg in Preussen.

Dujardin, Félix.

1845. Histoire naturelle des helminthes ou vers intestinaux, 654 pp., 12 pls. Paris.

Ercolani, G. B.

1875. Osservazioni elmintologische sulla dimorfobiosi nei nematodi, sulla Filaria immitis e sopra una nuova specie di Distoma dei cani. Mem. Acad. Sci. Ist. Bologna, ser. 3, vol. 5, no. 3, pp. 391-441, 1 pl., figs. 1-9.

Faust, E. C.

1929. Human helminthology. A manual for clinicians, sanitarians and medical zoologists, 618 pp., figs. 2-297, 1 pl. Philadelphia. 
Fischer, P. M.

1883. Über den Bau von Opisthotrema cochleare nov. genus; nov. spec. Ein Beitrag zur Kenntnis der Trematoden. Diss. 42 pp., 1 pl.

1884. Idem. Zeitschr. für wiss. Zool., vol. 40, no. 1, pp. 1-41, pl. 1. Fischoeder, Franz.

1901. Die Paramphistomiden der Saügethiere. Zool. Anz. vol. 24, pp. 367-375.

1902. Die Paramphistomiden der Saügetiere. Diss. 59 pp., 4 figs. Königsberg.

1903. Idem. Zool. Jahrb. (Abt. Syst.), vol. 17, nos. 4-6, pp. 485-660, figs. A-Q, pls. 20-31, figs. 1-104.

FuHRMANN, OtTo.

1929. Zweite Klasse des Cladus Platyhelminthes: Trematoda. Handbuch der Zoologie (Kükenthal und Krumbach), vol. 2, Lief. 3, Teil 2, Bogen 1-8, pp. 1-128, figs. 1-171. Berlin and Leipzig.

Gmelin, Johann Friedrich.

1790. Caroli à Linné . . Systema naturae per regna tria naturae, secundum classes ordines, genera, species cum characteribus, differentiis, synonymis, locis, vol. 1. Editio decima tertia, aucta, reformata, cura Jo. Fred. Gmelin, pt. 6 (Vermes), pp. 3021-3910.

Goeze, Johann August Ephraim.

1782. Versuch einer Naturgeschichte der Eingeweidewürmer thierischer Körper, 471 pp., 44 (35) pls. Blankenburg.

Goто, S., and Ozaki, Y.

1930. Brief notes on new trematodes III. Jap. Journ. Zool., vol. 3, no. 1, pp. 72-82, figs. $1-7$.

GurLt, E. F.

1831. Lehrbuch der pathologischen Anatomie der Haus-Saügethiere. Nebst einen Anhange, welcher die Beschreibung der bei den Haus-Saügethieren vorkommenden Eingeweidewürmer enthält, vol. 1, 399 pp. Berlin.

J ̈̈gerskiöld, Leonard Axel Krister Eduard.

1891. Über den Bau des Ogmogaster plicatus (Creplin) (Monostomum plicatum Creplin). K. Svenska Vetensk.-Akad. Handl., new ser., vol. 24 , pt. 1 , no. 7,32 pp., 2 pls., figs. 1-16. Stockholm.

1896. Über Monostomum lacteum n. sp. Zoologiska Studier. Festskrift Wilhelm Lilljeborg, pp. 165-177, 1 fig., pl. 9, figs. 1-9. Upsala.

1908. Kleine Beiträge zur Kenntnis der Vogeltrematoden. Centralb. für Bakt., Parasit. und Infekt., Abt. 1, Orig., vol. 48, no. 3, pp. 302-317, figs. 1-7.

JoHNSTON, S. J.

1913. On some Queensland trematodes, with anatomical observations and descriptions of new species and genera. Quart. Journ. Micr. Sci., new ser., vol. 59, no. 3 , pp. $361-400$, pls. 22-27, figs. 1-42.

JoHnston, T. HARVEY.

1931. New trematodes from the subantaretic and antaretic. Austral. Journ. Exper. Biol. and Med. Sci., vol. 8, no. 2, pp. 91-98.

Kossack, W.

1910. Neue Distomen. Centralb. für Bakt., Parasit. und Infekt., Abt. 1, Orig., vol. 56, no. 2, pp. 114-120, figs. 1-4, 1 pl., figs. $1-8$.

LARUe, George R.

1926. A trematode with two ani. Journ. Parasitol., vol. 12, no. 4, pp. 207209, 1 fig. 
LEIDY, JosEPH.

1891. Notices of Entozoa. Proc. Acad. Nat. Sci. Philadelphia, vol. 42 (ser. 3, vol. 20), no. 3, pp. 410-418, Oct.-Dec., 1890.

LEIPER, ROBERT T.

1908. An account of some helminthes contained in Dr. Wenyon's collection from the Sudan. 3d Rep. Wellcome Research Lab., pp. 187-199, figs. 44-50, pls. 21-22. London.

Leiper, Robert T., and Atkinson, E. L.

1915. Parasitic worms, with a note on a free living nematode. British Antaretic Expedition, 1910, Nat. Hist. Rep., Zool., vol. 2, no. 3, pp. 19-60, figs. 1-11, pls. 1-5, figs. 1-42. London.

LeUCKART, RUdOLPH.

1874. Bericht über die wissenschaftlichen Leistungen in der Naturgeschichte der niederen Thiere während der Jahre 1872-1875. Arch. für Naturg., Jahr. 40, vol. 2, pp. 401-505.

Linnaeus, Carolus.

1758. Systema naturae per regna tria naturae, secundum classes, ordines, genera, species, cum characteribus, differentiis, synonymis, locis. Editio decima, reformata. Vol. 1, 823 pp. Holmiae.

Linstow, Otto Friederich Bernhard, von.

1904. Neue Helminthen. Centralb. für Bakt., Parasit. und Infekt., Abt. 1, Orig., vol. 37, no. 5, pp. 678-683, figs. 1-11.

LÖNNBERG, E.

1891. Mitteilungen über einige Helminthen aus dem zool. Museum der Universität zu Kristiania. Biol. Fören. Förhandl,, Verh. Biol. Ver. in Stockholm, vol. 3, nos. 4-6, pp. 64-78, pl. 2, figs. 1-9.

Looss, Arthur.

1885. Beiträge zur Kenntnis der Trematoden. Distomum palliatum nov. spec. und Distomum reticulatum nov. spec. Zeitschr. für wiss. Zool., vol. 41, no. 3, pp. 390-446, pl. 23, figs. 1-30.

1896. Recherches sur la faune parasitaire de l'Egypte. Première partie. Mém. Inst. Égypte, vol. 3, pp. 1-252, pls. 1-16, figs. 1-193.

1899. Weitere Beiträge zur Kenntnis der Trematoden-Fauna Aegyptens, zugleich Versuch einer natürlichen Gliederung des Genus Distomum Retzius. Zool. Jahrb. (Abt. Syst.), vol. 12, nos. 5-6, pp. 521-784, figs. 2-b, pls. 24-32, figs. 1-90.

1900. Nachträgliche Bemerkungen zu den Namen der von mir vorgeschlagenen Distomidengattungen. Zool. Anz., vol. 23, pp. 601-608.

1901. Natura doceri, ein Erklärung und Begründung einiger Grundsätze, welche mich bei meinen "Versuche einer naturlichen Gliederung des Genus Distomum Retzius geleitet haben." Centralb. für Bakt., Parasit. und Infekt., Abt. 1, vol. 29, no. 5, pp. 191-210.

1902. Uber neue und bekannte Trematoden aus Seeschildkröten. Nebst Erörterungen zur Sytematik und Nomenclatur. Zool. Jahrb. (Abt. Syst.), vol. 16, no. 3-6, pp. 411-894, figs. A-B, pls. 21-32, figs. 1-181.

1912. Uber den Bau einger anscheinend seltner Trematoden-Arten. Zool. Jahrb., Suppl. 15, vol. 1, Festschr. 60. Geburtst. J. W. Spengel, pp. 323-366, pls. 17-19, figs. 1-22.

LüHe, Max.

1899. Zur Kenntnis einiger Distomen. Zool. Anz., vol. 22, pp. 524-539.

1908. Zur Systematik und Faunistik der Distomen. 1. Die Gattung Metorchis Looss, nebst Bemerkungen über die Familie Opisthorchiidae. Centralb. f. Bakt., Parasit. und Infekt., Abt. 1, Orig., vol. 48, no. 4, pp. 428 436 , figs. 1-6. 
LüHe, Max-Continued.

1909. Parasitische Plattwürmer. 1: Trematodes. Süsswasserfauna Deutschlands (Brauer), vol. 17, 217 pp., 188 figs. Jena.

MaCCallum, G. A.

1916. Some new species of parasitic trematodes of marine fishes. Zoopathologica, vol. 1, no. 1, pp. 3-38, figs. 1-16.

Marchi, Pietro.

1873. Sopra una specie nuova di Distomum trouvata nelle intestina del Delphimus tursio. Atti Soc. Ital. Sci. Nat. (1872-73), vol. 15, no. 4, p. 304, pl. 5, fig. B. Milan.

Morgan, D. O.

1927. Studies on the family Opisthorchiidae Braun, 1901, with a description of a new species of Opisthorchis from a Sarus crane (Antigone antigone). Journ. Helminth., vol. 5, no. 2, pp. 89-104, figs. 1-11.

Mühling, Paul.

1896. Beiträge zur Kenntnis einiger Trematoden. Centralb., für Bakt., Parasit. und Infekt., Abt 1, vol. 20, no. 16-17, pp. 588-590.

1898a. Studien aus Ostpreussens Helminthfauna. Vorläufige Mittheilung. Zool. Anz. vol. 21, pp. 16-24.

1898b. Die Helminthen-Fauna der Wirbeltiere Ostpreussens. Arch. für Naturg., Jahr. 64, vol. 1, no. 1, pp. 1-14, pls. 1-14, figs. 1-28.

NAzMI, M.

1930. A new trematode parasite from the domestic goose. Ann. Mag. Nat. Hist., ser. 10, vol. 6, pp. 377-380, figs. 1-3.

Nicoll, William.

1909. Studies on the structure and classification of the digenetic trematodes. Quart. Journ. Micr. Sci., new ser., vol. 53, no. 3, pp. 391487 , pls. $9-10$, figs. $1-28$.

ODHNER, TeODOR.

1905. Die Trematoden des arktischen Gebietes (In Römer and Schaudinn, Fauna Arctica, vol. 4, pt. 2, pp. 291-372, 4 figs., pls. 2-4. Jena.)

1910a. Microlistrum Braun, eine angebliche Distomengattung. Zool. Anz., vol. 35 , nos. 12-13, pp. 350-356, 1 fig.

1910b. Über Distomen, welche den Excretionsporus als Anus verwenden können. Zool. Anz., vol. 35, nos. 14-15, pp. 432-433.

1910c. Nordostafrikanische Trematoden, grosstenteils vom Weissen Nil (von der Schwedischen Zoologischen Expedition gesammelt), 170 pp.. 14 figs., 6 pls. (Results of the Swedish Zoological Expedition to Egypt and the White Nile 1901, under the direction of L. A, Jägerskiöld). Uppsala.

1911. Zum natürlichen System der digenen Trematoden. 3 (Ein weiterer Fall von sekundärem Anus). Zool. Anz., vol. 38, no. 4, pp. 97-117, figs. 1-8.

1914. Die Verwandtschaftsbeziehungen der Trematodengattung Paragonimus Brn. Zool. Bidrag Uppsala, vol. 3, pp. 231-(246), figs. 1-5.

1926. Protofasciola n. g., ein Prototypus der grossen Leberegels. Ark. för Zool., vol. 18, no. 3, pt. A, art. 20, pp. 1-7, figs. 1-2. Stockholm.

1928. Weitere Trematoden mit Anus. Ark. för Zool., vol. 20, no. 2, pt. B, art. 2, pp. 1-6, figs. 1-5. Stockholm.

\section{Olsson, Peter.}

1893. Bidrag till skandinaviens helminthfauna. K. Svenska Vetensk.Akad. Handl., new ser., vol. 25 (1892), no. 2, art. 12, 41 pp., pls. 1-5. figs. 1-81. Stockholm. 
OzAKI, Y.

1925. Preliminary notes on a trematode with anus. Journ. Parasitol., vol. 12 , no. 1 , pp. 51-53, pl. 7, figs. 1-2.

1928. On some trematodes with anus. Jap. Journ. Zool., vol. 2, no. 1, pp. 5-33, figs. 1-17.

Parona, Corrado.

1896. Interno ad alcuni distomi nuovi o poco noti. Atti Soc. Ligust. Sci. Nat. e Geogr., vol. 7, no. 3, pp. 162-180, figs. 1-7. Geneva.

Poche, Franz.

1926. Das System der Platodaria. Arch. für Naturg., vol. 91 (1925), Abt. A, no. 2 , pp. $1-240$, figs. $1-5$, pls. $1-3$, figs. $1-95$; no. 3 , pp. $241-458$, figs.

POIRIER, J.

1886. Trematodes nouveaux ou peu connus. Bull. Soc. Philom. Paris, ser. 7, vol. 10 (18S5-86), pp. 20-40, pls. $1-4,30$ figs.

Pratt, H. S.

1911. On Galactosomum cochleariforme Rudolphi. Zool. Anz., vol. 38, nos. 5-6, pp. 143-148, figs. 1-5.

Price, Emmett W.

1931. A new species of trematode of the family Heterophyidae, with a note on the genus Apophallus and related genera. Proc. U. S. Nat. Mus., vol. 79 , art. 17 , pp. 1-6, 1 fig.

RaIlliet, Alcide.

1896. Quelques rectifications à la nomenclature des parasites. Rec. Méd. Vêt., v. 73, ser. 8, vol. 3, no. 5, pp. 157-161.

RaNSOM, Brayton HowaRd.

1920. Synopsis of the trematode family Heterophyidae with descriptions of a new genus and five new species. Proc. U. S. Nat. Mus., vol. 57, pp. $527-573$.

RATZ, S. von.

1000. Parasitologiae jegyzetek. Veterinarius, vol. 23, no. 19, pp. 525-534, figs. $1-4$.

Rivolta, Sebistiano.

1884. Sopra una specie di Distoma nell gatto e nel cane. Giorn. Anat, Fisiol. e Patol. Anim., vol. 16, no. 1, np. 20-28, pl. 1, figs. 1-5. Pisa.

Rudolphi, Carl Asmund.

1802. Fortsetzung der Beobachtungen iber đie Eingeweidewürmer. Arch. für Zool. und Zoot, vol. 3, no. 1, pp. 61-125, pl. 2.

1809. Entozeorum sive vermium intestinalium historia naturalis, vol. 2, 457 ip., pls. 7-12. Amsterdam.

1819. Entozoorum synopsis cui accedunt mantissa duplex et indices locupletissimi, 811 pp., 3 pis. Berlin.

Siebold, Care Theonor Ernst von.

1836. Helminthologisebe Beiträge. Zweiter Beitrag. Syngamus irachealis. Ein doppelleibiger Eingeweidewurm. Arch. für Naturg., Jahr. 2, vol. 1, pp. 105-116, pl. 3, figs. 1-2.

SkRJABIn, K. I.

1915. Odhneriella rossica nov. gen. n. sp.--Возбудитель печеночно-глистной болезни моржей [Odhneriella rossica n. g., n. sp., as the cause of a helminthiasis of the liver in the walrus, odobaenus rosmarus,] [Russian text.] Arkh. Vet. Nak, vol. 45, no. 11 pp. 1057-1064, 1 fig. 
SKRJABIN, K. I.-Continued.

1923. Өтюды по изучению паразитических червей плотаядных. II. Ciureana quinqueangularis n. g. n. sp., новая кишечная трематода кошки [Contributions to the study of parasitic worms of carnivores. II. Ciureana quinqueangularis n. g., n. sp., a new intestinal trematode of the cat.] [Russian text.] Trudy Gosudarstv. Inst. Eksper. Vet., vol. 1, no. 1, pp. 67-71, 1 fig. Moscow.

SkrJabin, H. I., and Lindtrop, G. T.

1919. Трематоды кишечника собак Донской области (Trematodes intestinales des chiens du Don.) [Russian text.] Izvest. Donsk. Vet. Inst., vol. 1, no. 1, pp. 30-43, 3 figs., 1 pl., 3 figs.; French summary, pp. $43-44$.

Sokoloff, Demetrio, and Caballero y C., Eduardo.

1932. Una nueva especie de trematodo parasito del intestino del manati, Schizamphistoma manati sp. n. Ann. Inst. Biol., Univ. Nac. Mexico, vol. 3, no. 2, pp. 163-167, figs. 1-5.

Sonsino, Prospero.

1890. Studi e notizie elimintologiche. Atti Soc. Toscana di Sci. Nat., Pisa. proc. verb., vol. 7, pp. 99-114.

Stiles, Charles Wardell.

1894. The anatomy of the large American fluke (Fasciola magna), and a comparison with other species of the genus (Fasciola, s. st.). Containing also a list of the chief epizoötics of fascioliasis (distomatosis) and a bibliography of Fasciola hepatica, by Albert Hassall. Journ. Comp. Med. and Vet. Arch., vol. 15, no. 3, pp. 161-178; no. 4 , pp. $225-243$, pls. $1-2$; no. 5 , pp. $299-313$, pls. $3-4$; bibliography of $F$. hepatica, by Albert Hassall, no. 6, pp. 407-417; no. 7, pp. $457-462$.

Stiles, C. W., and Hassall, Albert.

1894. A preliminary catalogue of the parasites contained in the collections of the United States Bureau of Animal Industry, United States Army Medical Museum, Biological Department of the University of Pennsylvania (Coll. Leidy) and in Coll. Stiles and Coll. Hassall. Vet. Mag., vol. 1, no. 4, pp. 245-253; no. 5, pp. 331-354.

1896. Notes on parasites 42-46. Vet. Mag., vol. 3, no. 3, pp. 151-161.

1900. A muscle fluke (Agamodistomum sp.) in American swine; the lung fluke (Paragonimus westermanni) in swine and its relation to parasitic haemoptysis in man (pp. 560-611, pls. 23-24, figs. 24-28) ; the conical fluke (Amphistoma cervi) of cattle slaughtered in the United States (p. 611, 1 fig.). (Notes on parasites, 50-52.) 16th Ann. Rep. Bureau of Animal Industry, U. S. Dept. Agr., 1899, pages and figs. cited.

1908. Index-catalogue of medical and veterinary zoology. Subjects: Trematoda and trematode diseases. Hyg. Lab. Bull. 37, U. S. Pub. Health and Marine Hosp. Serv., 401 pp.

1926. Key-catalogue of the worms reported for man. Hyg. Lab. Bull. 142, U. S. Pub. Health Serv., $196 \mathrm{pp}$.

Stossich, Michele.

1892. I distomi dei mammiferi. Estratto dal programma della Civica Scuola Reale Superiore, $42 \mathrm{pp}$. Trieste.

1904. Alcuni distomi della collezione elmintologica del museo zoologico di Napoli. Ann. Mus. Zool. Univ. Napoli, new ser., vol. 1, no. 23, pp. 1-14, pl. 2, figs. 1-3. 
STUNKARD, H. W.

1929. The parasitic worms collected by the American Museum of Natural History Expedition to the Belgian Congo, 1909-1914. Bull. Amer. Mus. Nat. Hist., vol. 58, art. 6, pp. 233-289, figs. 1-37.

1930. Another trematode with two anal openings (abstract of paper to be read before Amer. Soc. Zool., Cleveland, Ohio, Dec. 30). Anat. Rec., vol. 47 , no. 3 , p. 363 .

Stunkard, H. W., and Alvey, C. H.

1929. A new liver fluke, Zalophotrema hepaticum, from the California sea lion, Zalophus californianus (abstract of paper to be read before Amer. Soc. Parasitol., Des Moines, Dec. 27-31). Journ. Parasitol., vol. 16, no. 2, pp. 106-107.

1930. The morphology of Zaiophotrema hepatioum, with a review of the trematode family Fasciolidae. Parasitology, vol. 22, no. 3, pp. 326-333, pl. 33, figs. 1-4.

Travassos, Lauro.

1929. Contribuicão ao conhecimento dos Heterophyidae. These vet. 31 pp., 1 fig.

Travassos, Lauro, and Vogelsang, Enrique.

1931. Novo tipo de trematodeo Opisthotrematidae. Bol. Biol., Rio de Janeiro, no. 19, pp. 143-147.

VINOGRADOV, K. N.

1892. О новомъ виды двуускки (Distomum sibiricum) въ печени человька [On a new species of distome (Distomum sibiricum) in the human liver.] [Russian text.] Izvest. Imp. Tomsk. Univ., vol. 4 (Trudy Tomsk. Obsh. Estestvois. (1890-91), vol. 3), pp. 116-130, figs. 1-5.

Weski, Oskar.

1900. Mitteilungen über Distomum lancea Dies. Centralb. für Bakt., Parasit. und Infekt., Abt. 1, vol. 27, nos. 16-17, pp. 579-583, 1 fig.

WIGDOR, MEYER.

1918. A new fluke from the dog. Journ. Amer. Vet. Med. Assoc., vol. 54, (new ser., vol. 7), no. 3, pp. 254-257, fig. 1-4.

WITENBERG, G.

1929. Studies on the trematode-family Heterophyidae. Ann. Trop. Med. and Parasit., vol. 23, no. 2, pp. 131-239, figs. 1-33.

1930. Corrections to my paper "Studies on the trematode family Heterophyidae.” Ann. Mag. Nat. Hist., ser. 10, vol. 5, pp. 412-414.

ZELLER, ERNST.

1874. Über Leucochloridium paradoxum Carus und die weitere Entwickelung seiner Distomenbrut. Zeitsch. für wiss. Zool., vol. 24, no. 4, pp. $564-578$. 


\section{ABBREVIATIONS USED ON PLATES}

ac. Acetabulum.

c. Cirrus.

c. p. Cirrus pouch.

es. Esophagus.

exp. Excretory pore.

g. p. Genital pore.

int. Intestine.

lc. Laurer's canal.

1v. Lymph vessels.

mg. Mehlis's gland.

oc. Oral canal. os. Oral sucker.

ov. Ovary.

ph. Pharynx.

ppr. Pars prostatica.

sr. Seminal receptacle.

sv. Seminal vesicle.

t. Testes.

ut. Uterus.

vd. Vitelline duct.

vit. Vitellaria.

vr. Vitelline reservoir.

68 


\section{$2 \mathrm{BHL}$ Biodiversity Heritage Library}

Price, Emmett W. 1932. "The trematode parasites of marine mammals." Proceedings of the United States National Museum 81(2936), 1-68. https://doi.org/10.5479/si.00963801.81-2936.1.

View This Item Online: https://www.biodiversitylibrary.org/item/32577

DOI: https://doi.org/10.5479/si.00963801.81-2936.1

Permalink: https://www.biodiversitylibrary.org/partpdf/10059

\section{Holding Institution}

Smithsonian Libraries

\section{Sponsored by}

Smithsonian

\section{Copyright \& Reuse}

Copyright Status: NOT_IN_COPYRIGHT

Rights: https://www.biodiversitylibrary.org/permissions/

This document was created from content at the Biodiversity Heritage Library, the world's largest open access digital library for biodiversity literature and archives. Visit BHL at https://www.biodiversitylibrary.org. 